\title{
Do Reorganization Costs Matter for Efficiency? Evidence from a Bankruptcy Reform in Colombia
}

\author{
Xavier Giné and Inessa Love*
}

\begin{abstract}
This paper studies the effect of reorganization costs on the efficiency of bankruptcy laws. We develop a simple model that predicts that in a regime with high costs, the law fails to achieve the efficient outcome of liquidating unviable businesses and reorganizing viable ones. We test the model using the Colombian bankruptcy reform of 1999. Using data from 1,924 firms filing for bankruptcy between 1996 and 2003, we find that the pre-reform reorganization proceeding was so inefficient that it failed to separate economically viable firms from inefficient ones. In contrast, by substantially lowering reorganization costs, the reform improved the selection of viable firms into reorganization. In this sense, the new law increased the efficiency of the bankruptcy system in Colombia.
\end{abstract}

World Bank Policy Research Working Paper 3970, July 2006

The Policy Research Working Paper Series disseminates the findings of work in progress to encourage the exchange of ideas about development issues. An objective of the series is to get the findings out quickly, even if the presentations are less than fully polished. The papers carry the names of the authors and should be cited accordingly. The findings, interpretations, and conclusions expressed in this paper are entirely those of the authors. They do not necessarily represent the view of the World Bank, its Executive Directors, or the countries they represent. Policy Research Working Papers are available online at http://econ.worldbank.org.

*Emails: xgine@worldbank.org and ilove@worldbank.org. Both authors are affiliated with the World Bank, 1818 H Street, Washington, DC 20433. We wish to thank Fernando Montes-Negret for sparking our interest in this topic, Enrique Aguirre and the Superintendencia de Sociedades for the data and Rodolfo Danies Lacouture, the Superintendent, for insightful comments on an earlier draft. We also wish to thank Jaime Alberto Gomez, Jorge Pinzón, Felipe Trias and Carlos Urrutia for very useful conversations about the intricacies of the bankruptcy law in Colombia. We finally wish to thank Rei Odawara for excellent research assistance and to Jishnu Das, Asli Demirguc-Kunt, Quy-Toan Do, Leora Klapper, Soledad Martínez Peria, Claudio Raddatz and Kenichi Ueda for valuable comments. 


\section{Introduction}

Nearly ninety countries around the world have reformed their bankruptcy codes since World War II and over half of them have done so during the last decade. The extent to which these reforms will succeed depends on their design and the context in which the new codes are binding (Claessens, S., et al., 2001; Franks and Loranth, 2005; Hart, 2000 and World Bank, 2004, 2005 and 2006). Yet, all countries seek to improve the efficiency of the bankruptcy system by encouraging the reorganization of viable firms and the liquidation of unviable ones. This requires a delicate balance (White, 1989). On the one hand, if the law is lenient towards failing firms, it will inevitably allow inefficient firms to continue operations. On the other, if the law favors liquidation, it will also liquidate viable firms.

Due to this trade-off, the design of bankruptcy laws is still a much debated topic (Claessens and Klapper, 2003; Smith and Strömberg, 2004 and references therein). The debate has focused on comparing two stylized bankruptcy proceedings: cash auctions or liquidations and structured bargainings or reorganizations. Critics of reorganizations argue that conflicting interests among claimholders and managers lead to excessively lengthy and costly negotiations (Baird, 1986; Aghion et al., 1992). Critics of liquidations claim that they contribute to the inefficient sale of assets due to market illiquidity and transaction costs (Shleifer and Vishny, 1992; Aghion et al., 1992). ${ }^{1}$

While there is a growing literature estimating the costs of bankruptcy (Bris et al. 2005 for a review), there is little empirical evidence assessing how these costs affect the ability of laws to separate viable businesses from unviable ones, a key to ensuring efficiency. This paper attempts to fill this gap by using a bankruptcy reform that took place in Colombia.

In the midst of financial crisis, facing a backlog of failing businesses entering a very inefficient bankruptcy process, Colombia adopted a new reorganization code in late 1999. This law, known as Law 550, streamlined the reorganization process by

\footnotetext{
${ }^{1}$ Using data from Sweden, Stromberg (2000) show that liquidations also suffer from conflicts of interest among claimholders.
} 
establishing shorter statutory deadlines for reorganization plans, reducing opportunities for appeal by debtors and requiring mandatory liquidation in cases of failed negotiations.

We present a simple model that describes the decision to reorganize or liquidate a financially distressed firm as a function of reorganization costs. In a regime with high idiosyncratic reorganization costs, some viable businesses may be liquidated if the costs they face are too high. In this case, the bankruptcy system fails to separate viable from unviable firms, resulting in inefficient outcomes. In contrast, when reorganization costs are low, the model predicts that better quality firms are more likely to choose reorganization, resulting in a clear separation between firms that reorganize and those that liquidate. In this regime, as a result of both lower costs and better selection, the recovery after reorganization is significantly improved thus contributing to more efficient outcomes. The Colombian reform can be seen as a natural experiment with two regimes that match our model - a pre-reform regime with high reorganization costs and the postreform regime with low costs.

We use a unique dataset obtained from the Colombian Superintendence of Companies which includes a total of 1,924 bankruptcy cases, representing the universe of cases filed between 1996 and 2004, conveniently spanning the reform episode. We also use data of about 14,000 active companies that report to the same Superintendence over the same time period. One attractive feature of the dataset is that it predominantly consists of non-listed firms thus complementing the US literature, which has focused mainly on public firms. ${ }^{2}$ The financial data we use come only from financial statements, and so we rely on accounting-based models (e.g. Z-score model of Altman 1968 and 2000) to construct an indicator of financial distress.

We show that the reform achieved a reduction in reorganization costs that made reorganization an attractive option for distressed but viable firms. First, we find that the duration of reorganization proceedings significantly decreases overall and also relative to the duration of liquidations with the new reorganization code. This finding supports our

\footnotetext{
2 The literature on reorganization costs in the US mostly draws conclusions from the relatively small number of public corporations (see for example Altman, 1984; Weiss, 1990 and Weiss and Wruck, 1998). A notable exception is Bris et al. (2005), which use a sample of 286 public and private firms, the largest sample in the US, and Davydenko and Franks (2005) who use a large sample of small firms from France, Germany and the UK.
} 
model's assumption of lower (indirect) costs after the reform. Second, under the old law, we observe that firms filing for reorganization are indistinguishable from those filing for liquidation based on several measures of financial health. In contrast, relatively healthier (and hence more viable) firms are more likely to file for reorganization after the new law, producing a clear separation in the distribution of the two types of firms. Finally, we find that the level of recovery after the reorganization episode is significantly improved under the new law. While under the old law firms hovered at about the same low level of financial health for years after entering into reorganization, we observe a clear recovery under the new law. We conclude that the new law increased the efficiency of the bankruptcy system in Colombia.

Previous bankruptcy studies analyze the existing laws of a given country or make comparisons across different countries. Evidence from the US Chapter 11 reorganizations offers mixed conclusions on the magnitude of these costs. While Altman (1984) and Hotchkiss (1995) among others find high Chapter 11 costs, Alderson and Betker (1995) and Maksimovic and Phillips (1998) find them to be low. More recently, Bris et al. (2005) show that reorganization costs are heterogeneous across firms but comparable to US Chapter 7 liquidations costs, although reorganizations as compared to liquidations preserve the assets better. In contrast, Thorburn (2000) finds that liquidations in Sweden, which have a statutory deadline, are faster and cheaper than reorganizations in the US. Bris et al. (2005), however, question the validity of the comparison because the US and Sweden differ from each other in many other ways besides the bankruptcy codes.

In this paper, we look at the impact of a statutory deadline in the reorganization proceeding but avoid country comparisons by studying a bankruptcy reform in a country. We exploit the fact that the reform only affects the reorganization proceeding, allowing us to compare firms that file for reorganization to firms filing for liquidation before and after the law. However, since the law was introduced because of a major financial crisis, we need to make sure that we can attribute the effects to the new law and not the changing macroeconomic conditions. ${ }^{3}$ Similarly, a gradual improvement of the judiciary system could also confound the results. We address these concerns by controlling for

\footnotetext{
${ }^{3}$ See Uribe and Vargas (2002) or Urrutia and Zárate (2001) for details about the causes and magnitude of the crisis.
} 
overall trends and making sure that the crisis did not affect differently reorganizations relative to liquidations. We find that the crisis had the same effect on both groups of firms, thus suggesting that our identification strategy is valid.

The rest of the paper is organized as follows. Section II develops the model and Section III outlines the main testable implications. Sections IV and V present and describe the data in detail. Section VI presents our empirical specifications, Sections VII and VIII discuss the main results and robustness tests and Section IX concludes. The background information on the bankruptcy system in Colombia and details of the new reorganization Law 550 of 1999 are presented in Appendix 1.

\section{Model}

In this section we develop a model in the spirit of White (1994) that focuses on the decision to reorganize or liquidate as a function of reorganization costs, which are specific to the firm (Bris et al., 2005).

\section{A. Assumptions}

At date 0 , firm $i$ obtains a loan to finance a project that yields an idiosyncratic return (cash-flow) of $x_{i 1}$ at date 1 and $x_{i 2}$ at date 2 . The lender (bank) agrees to give the loan in exchange for repayments $p$ at dates 1 and 2 . The repayment schedule is the same for all firms.

If the return from the project at date $1, x_{i 1}$, is lower than $p$ then firm $i$ is in financial distress. We assume that at this point the bank gains control of the firm and decides whether to liquidate or reorganize the firm. If liquidation is chosen, the bank

obtains $L+x_{i 1}, L<p$ where $L$ is the scrap value of the firm's assets. If instead reorganization is chosen, the bank obtains current cash-flow $x_{i 1}$ and allows the firm to continue its operations until date 2 when a new payment $p_{i 2}$ will be made. At date 2 , the value of the firm's assets is zero and the firm is shut down. Thus, liquidation values at each date are equal for all firms.

Since managers obtain a payoff of zero if the firm is liquidated but may receive a positive payoff (net of bank repayment and reorganization costs) if the firm is 
reorganized, they will always prefer reorganization to liquidation. The bank however must weight the immediate gain of liquidation against expected net gain of reorganization.

Letting the firm's net return at date 2 be $n_{i}\left(x_{i 2}\right)=x_{i 2}-c_{i}\left(x_{i 2}\right)$, repayment to the bank $p_{i 2}$ will be $p$ if net return satisfies $n_{i}\left(x_{i 2}\right) \geq p$ but it will only equal net return $n_{i}\left(x_{i 2}\right)$ if $n_{i}\left(x_{i 2}\right)<p$. The cost of reorganization $c_{i}(\cdot)$ may include fixed and variable costs which may depend on the idiosyncratic return $x_{i 2}$ itself. But more importantly, as shown in Bris et al. (2005) for the US and in our empirical results of Section VII.A, reorganization costs are specific to the firm. Thus, firms may face different expected reorganization costs at date 1 despite realizing the same returns at dates 1 and $2 .{ }^{4}$ This is the reason why the cost function $c_{i}(\cdot)$ is indexed by $i$. Without loss of generality, we assume that these costs are bounded above by $\bar{c}\left(x_{i 2}\right)$. Thus, $0 \leq c_{i}\left(x_{i 2}\right) \leq \bar{c}\left(x_{i 2}\right)$. The only other restriction we impose on these reorganization costs is that the net return function for firm $i$ at date $2, n_{i}\left(x_{i 2}\right)$, be strictly increasing in $x_{i 2}$.

We assume that there are two types of firms in the economy: economically viable and unviable firms. A fraction $\theta$ of economically viable firms obtain returns $x$ from the probability density function $f_{H}(x), x \geq 0$ while unviable (inefficient) firms draw $x$ from the distribution $f_{L}(x), x \geq 0$. By definition, the density functions $f_{j}(\cdot), j=L, H$ are such that $E\left[p_{2} \mid H\right]>p>E\left[p_{2} \mid L\right]$, where $E\left[p_{2} \mid j\right], j=L, H$ can be written as

$$
E\left[p_{2} \mid j\right]=\int_{0}^{n^{-1}(p)} n\left(x_{2}\right) f_{j}\left(x_{2}\right) d x_{2}+p\left[1-F_{j}\left(n^{-1}(p)\right)\right]
$$

\footnotetext{
${ }^{4}$ The difference in reorganization costs may come from the specific nature of the firm's assets or operations, or the bankruptcy process itself, which could carry a large idiosyncratic component, for example, the length of the process could depend on qualifications and experience of a judge or promoter assigned to the case.
} 
In addition, we assume that $f_{j}(\cdot), j=L, H$ satisfy the strict monotone likelihood ratio property (MLRP). ${ }^{5}$ With this assumption, the realized return $x_{i 1}$ provides information about the expected return $x_{i 2}$ that will be taken into account by the bank when deciding whether to liquidate or reorganize a distressed firm. In addition, since at date 0 the bank only knows the proportion of viable firms and loan size is equal for all firms, the repayment schedule is also the same for every firm.

Assuming no discounting, the bank will reorganize firm $i$ at date 1 if

$$
E\left[p_{i 2} \mid x_{i 1}\right] \geq L
$$

Using Bayes Law and dropping subscript $i$, the expectation in the left hand side can be written as follows:

$$
\begin{aligned}
E\left[p_{2} \mid x_{1}\right] & =\operatorname{Pr}\left[H \mid x_{1}\right] E\left[p_{2} \mid H\right]+\operatorname{Pr}\left[L \mid x_{1}\right] E\left[p_{2} \mid L\right] \\
& =\frac{f_{H}\left(x_{1}\right) E\left[p_{2} \mid H\right]+f_{L}\left(x_{1}\right) E\left[p_{2} \mid L\right]}{\theta f_{H}\left(x_{1}\right)+(1-\theta) f_{L}\left(x_{1}\right)} .
\end{aligned}
$$

where $E\left[p_{2} \mid j\right], j=L, H$ is given by Equation 1 .

\section{B. Implications}

We now discuss the predictions of our model in the context of the Colombian reform. Since the main purpose of Law 550 was to shorten the statutory deadlines of reorganizations, we model it as a reduction in the maximum $\operatorname{cost}$ from $\bar{c}_{B}(\cdot)$ (before Law 550) to $\bar{c}_{A}(\cdot)$ (after Law 550), $\bar{c}_{B}(\cdot)>\bar{c}_{A}(\cdot)$. We interpret this cost as the time it takes to approve a reorganization plan. A potential indirect cost is the time that managers have to spend in meetings with creditors. Less time involved in actually running the firm may

\footnotetext{
${ }^{5}$ Let $\bar{x}>\underline{x}$, then strict MLRP implies that $f_{H}(\bar{x}) f_{L}(\underline{x})-f_{L}(\bar{x}) f_{H}(\underline{x})>0$. See Milgrom (1981) for further details.
} 
result in lower cash-flows. Likewise, a prime direct cost are lawyer's fees, and so the shorter the proceeding, the lower the expenses should be.

Figure 1 explains in a graph the decision that banks face at date 1 by plotting the payoffs to liquidation and reorganization in Equation 2 in the relevant range of observed cash-flow at date $1, x_{i 1}$, when the firm is in distress, $x_{i 1}<p$. The liquidation value is the same in both panels because only reorganization was affected by the change in the law. The expected payoff to reorganization can be written as:

$$
E\left[p_{i 2} \mid x_{i 1}\right]=\left\{\begin{array}{c}
E\left[n_{i}\left(x_{i 2}\right) \mid x_{i 1}\right] \text { if } x_{i 1}<x_{i p} \\
p \text { otherwise }
\end{array}\right.
$$

where $x_{i p}$ is defined as the observed cash-flow at date 1 that makes the net expected payoff to reorganization equal to $p .{ }^{6}$ Given the assumption of MLRP, expected net cash-flow $n_{i}\left(x_{i 2}\right)$ at date 2 is increasing in observed cash-flow at date $1, x_{i 1}$. For a firm that expects reorganization costs to be zero, expected net cash-flow for a distressed firm equals that of an active firm and is simply the expected cash-flow $x_{i 2}$ itself. This is given by the top increasing line as $x_{1}$ goes from 0 to $x_{p}$, and the horizontal line at $p$ for $x_{1}>x_{p}$. Since cash-flows are not affected by the law, the payoff to reorganization for firms that expects zero costs is the same (as shown in the left and right panel of Figure 1). The key difference arises when expected reorganization costs are positive. The bottom increasing line from 0 to $p$ plots expected net cash-flow $n_{i}\left(x_{i 2}\right)$ for a firm that expects the maximal reorganization costs. As described above, these expected costs are higher before the law (left panel) than after (right panel).

Because costs are specific to the firm, a firm in distress before the law with a relatively high cash-flow could be liquidated if the expected reorganization costs were high, while a firm with a low cash-flow could be reorganized if the expected

\footnotetext{
${ }^{6}$ More formally, $x_{i p}$ is such that $E\left[n_{i}\left(x_{i 2}\right) \mid x_{i p}\right]=p$. Notice that $x_{i p}$ could be higher, equal or lower than $p$. Since reorganization costs only matter if the firm is in financial distress, that is, when cash-flows at date 1 satisfy $0 \leq x_{i 1} \leq p$, if the threshold $x_{i p}$ is such that $x_{i p}>p$, then $x_{i p}$ is irrelevant. This is the case in both panels of Figure 1 when expected reorganization costs are maximum. However, when expected reorganization costs are zero we have that $x_{i p}<p$ and thus $x_{i p}$ is plotted in Figure 1.
} 
reorganization costs were low. In other words, depending on the distribution of expected reorganization costs across firms, the distribution of cash-flows between firms that restructure and those that liquidate before the law could be the same. In this case, the law induces reorganization costs that are so high that prevent firms with relatively high cashflows (most likely economically viable firms) from reorganizing.

After the law is introduced, however, reorganization costs decrease substantially. There is a threshold cash-flow at date $1, x^{*}$, such that if date 1 cash-flow satisfies $x_{1}>x^{*}$, then it is never optimal to liquidate even if the firm expect the maximum reorganization costs. Firms with $x_{1}<x^{*}$ may still be either liquidated or reorganized, depending on the expectation of $c_{i}(\cdot)$. As a result, liquidated firms will tend to have lower cash-flows than reorganized firms. ${ }^{7}$ After the reform, reorganization costs are lower, so banks prefer to always reorganize firms with relatively high cash-flows. In essence, the bankruptcy system is able to separate and rehabilitate firms that are expected to be viable from those that are not.

\section{Discussion}

The model just described is very stylized but does deliver the prediction that if costs are large enough, the bankruptcy law may fail to achieve one of its prime objectives: the screening of viable firms from unviable ones. Simplicity however comes at the cost of abstracting from potentially important issues. For example, it has only one creditor, like in Kahl (2002), so we do not model coordination frictions among creditors, as in Bulow and Shoven (1978), Gertner and Scharfstein (1991) or Strömberg (2000). We also abstract from ex-ante efficiency discussions, as we only focus on the decision to reorganize or restructure once the firm is in financial distress.

\footnotetext{
${ }^{7}$ Figure 1 is drawn assuming that the expected repayment to the bank when the firm does not expect reorganization costs (or expects net cash-flow $x_{2}$ ) is higher than its liquidation value even if the firm obtained zero cash-flow at date 1 . If this assumption does not hold, then firms with very low cash-flow would always be liquidated, before and after the reform. It would still be the case that in the high cost regime (before Law 550), firms with relatively high cash-flows could still be liquidated if reorganization costs expected by the firm were large enough.
} 
The model however can easily be extended to a setup similar to Kahl (2002) to explore another dimension of efficiency in bankruptcy laws. Kahl (2002) presents an interesting model where in the context of uncertainty about the firm's viability, a strategy of delayed liquidation where the firm is allowed to continue but is kept highly leveraged may be desirable, as it allows creditors to observe future firm performance and to make a better informed decision. In our model of heterogeneous and uncertain reorganization costs, banks could regret having reorganized firms that ex-post ended up with a large cost of reorganization. If at date 1 distressed firms were allowed to continue producing without incurring reorganization costs but actual reorganization cost were still realized at date 2 , then if banks were given another chance to choose between liquidation and continuation, they would in some cases revert their decisions and force firms to a mandatory liquidation. The likelihood of this event depends on how large the reorganization costs can be. Because reorganization costs are significantly lower after the reform, the number of reorganization cases that end up in mandatory liquidation should be lower. We test this prediction below.

Finally, the model assumes that liquidation values and the distribution of cashflows remain unaffected by the introduction of the law. But because the law is introduced during a major crisis, one could make the argument following Shleifer and Vishny (1992) that adverse macroeconomic conditions may lower liquidation values (as well as the distribution of cash-flows). This is particularly important in the context of the model because the result of separation of viable and unviable firms obtained from a relative improvement of reorganization costs could also come from lower liquidation values. ${ }^{8}$ We offer a test of this assumption below.

\section{Testable Assumptions and Implications}

This section describes the testable assumptions and implications of the model that follow from the introduction of the new law: (A) reduction in reorganization costs, (B)

\footnotetext{
${ }^{8}$ Changes in the distribution of cash-flows are analogous to changes in reorganization costs. A worsening of the distribution of cash-flows (as an increase in reorganization costs) will result in more liquidations and thus will work against the separation of viable from unviable firms.
} 
selection of healthier firms into reorganization, and (C) faster recovery of reorganized firms.

The results are driven by two different types of firms: those that would have filed for reorganization under both laws, and those that would not file under the old law (either because they filed for liquidation or were involved in out-of-court settlements) but now file under the new reorganization proceeding. We consider them together in the analysis of Section VI.

\section{A. Duration of Reorganization}

In light of our model, we interpret the effect of Law 550 as a decline in reorganization costs. One obvious component of the overall cost of reorganization is the time it takes to approve the reorganization plan (Franks and Torous, 1989 or more recently Bris et al., 2005). Since the new law limited the negotiations to a maximum of eight months, one would expect total costs (direct and indirect) to also decrease on average.

Hypothesis A1. The duration of reorganization decreases after the new law is introduced (overall and relative to liquidations).

The model assumes that liquidation values did not change. We can test this assumption by using indirect liquidation costs (measured by the duration of liquidations) as a proxy for liquidation value: ${ }^{9}$

Hypothesis A2. The duration of liquidation remains constant, and thus liquidation values do not change.

To test the validity of these hypotheses, we compare the length of reorganization and liquidation cases before and after the law.

\section{B. Selection into Reorganization}

The main implication from the model is that the reform contributed to the efficiency of the bankruptcy law by separating viable from non viable firms. Before the

\footnotetext{
${ }^{9}$ Liquidation values could also be driven by the fluctuations in the scrap value of the assets that are uncorrelated with the costs of liquidation as measured by the length of the process. We don't have adequate data to test this assumption.
} 
law, reorganization was so inefficient that it failed to separate viable from unviable firms. Here we test whether the new Law 550 improved the efficiency of the bankruptcy system by allowing viable firms to choose reorganization as a now attractive alternative.

Hypothesis B1. Before the new law, liquidating firms are indistinguishable from reorganizing firms, while after the law, liquidating firms have weaker financial health, relative to reorganizing firms.

Also as discussed in the previous section, the resulting efficiency of the reorganization procedure should result in a lower proportion of reorganization cases that end up in mandatory liquidation.

Hypothesis B2. The number of reorganizations that result in mandatory liquidation is lower after the new law.

\section{Recovery after Reorganization}

As a direct result of both lower costs and better selection, the recovery of distressed firms after reorganization should improve significantly.

Hypothesis C. Reorganized firms recover faster after the new law.

\section{Data}

The data used come from the Superintendence of Companies of Colombia. We use two different datasets, bankruptcy filings and financial statements. We now explain each one in more detail.

\section{A. Bankruptcy Data}

These data include the universe of liquidations (L) and reorganizations (R) filed with the Superintendence from 1995 until 2004. R firms are divided into Concordato and Acuerdo, depending on the time of the filing. Before 2000 (under Law 222), the firm filed a Concordato, while after 2000 (under the Law 550), it filed an Acuerdo.

All cases report the starting date but only about half report the ending date. Many of the ending dates are missing because the process is still ongoing, especially among 
liquidations. ${ }^{10}$ For firms that have a start and end of the filing, we construct a DURATION variable that measures the length of the proceeding in months.

Since reorganization automatically ends in mandatory liquidation if negotiations break down, in many cases the same firm files first for reorganization and later for liquidation. In our analysis, we only use data of the firm's initial filing. Thus, if the firm first applied for reorganization and then was forced to liquidate, we only use data from its reorganization. While this shortens our liquidation sample by about half of the total number of liquidations observed, this rule ensures that all firms enter liquidation directly, and not as a result of failed reorganizations.

Table 1A reports the distribution of firms that entered bankruptcy proceedings under each of the three cases. We have a total of 1,924 initial filings. About a quarter of these firms file for liquidation directly and the rest of file for reorganization. About half of our sample filed under the old law.

In addition to initial filings, Table $1 \mathrm{~A}$ also reports the total number of mandatory liquidations in the second column. A total of 214 firms that originally filed a Concordato and 184 firms that filed an Acuerdo have later on filed for liquidation. ${ }^{11}$ As discussed above, all these secondary filings are excluded from analysis. This allows us to focus on the initial filing decision, which we believe is the most affected by the legal reform.

\section{B. Financial Data}

In addition to firms that filed for liquidation or reorganization, we have data for all firms that periodically report to the Superintendence of Companies. By law, all firms with sales or assets exceeding 6,000 minimum wages in the fiscal year, foreign branches, commercial consortiums, livestock funds and special interest firms as declared by the president are required to provide financial statements once a year to the Superintendence. Our sample consists then of larger firms although virtually none is listed in the Colombian stock exchange. Table 1B reports the sector breakdown. The data cover the

\footnotetext{
${ }^{10}$ We found 13 Concordato cases with a recorded starting date after 2000. Since the new law was passed in December 1999, there should be no Concordato cases after 1999. We therefore drop these 13 cases from our sample.

${ }^{11}$ In addition, 50 firms that filed a Concordato under the old law, later filed an Acuerdo under the new law (not shown in Table 1A). Of these cases, 21 failed and moved to mandatory liquidation.
} 
period 1996-2003 and contain about 14,000 firms with close to 70,000 firm-year observations. We refer to this as the sample of active firms.

We merged our sample of bankrupt firms with the financial data sample using a firm unique identifier. Out of 1,924 bankrupt firms only 1,201 firms have financial data in at least one year, resulting in a total of about 5,400 firm-year observations. Our panel is rather unbalanced and for many firms we only have one or a few years of data available; some firms have only pre-filing data and some have only post-filing data. The last three columns of Table 1A give the distribution of these firms with financial data across three types of proceedings and initial time of the filing.

For our bankrupt firms we create a timeline around the time of filing. We refer to the year of filing as year 0 , the first year after filing as +1 and the year before filing as -1 .

To study the filing decision, we would like to use financial data at the time of filing (i.e. year 0). However, for some firms we have no data for the filing year, but have some data from previous years. ${ }^{12}$ To increase our sample size we use all firms that have data for either year $0,-1$ or -2 . In total, we have 1,032 bankrupt firms with pre-filing financial data. We refer to this as the bankrupt sample.

In addition to the filing decision, we are interested in comparing the speed of recovery after filing for reorganization before and after the new law. To do this we require pre and post filing data. To ensure that observed changes in performance are not caused by changes in sample composition, we construct a sample of firms with available financial data for the filing year and at least one year pre and post filing. Due to this stricter data requirement, we have only around 300 firms with about 2,000 firm-year observations. We refer to this as our time-series sample.

\section{Matched Sample of Active Firms}

Our filing data include years with different macroeconomic conditions, including an episode of major financial crisis in 1999. To control for differences in macroeconomic conditions affecting our bankrupt firms, we create a matched sample of active firms. For

\footnotetext{
${ }^{12}$ For example, we have 794 firms with data for the filing year. In addition, we have 166 firms with financial data for year -1 (but no data for the filing year) and additional 73 firms have data for year -2 (but no data for year 0 or -1$)$.
} 
each firm in our bankrupt sample we pick one active firm that matches the bankrupt firm by size, year and industry. First, we pick all active firms in the same industry and same year as the bankrupt firm. ${ }^{13}$ Then, for each bankrupt firm we find an active firm (among all active firms available in the same year and industry) that is closest in absolute distance to the size of the bankrupt firm, based on total assets. We make sure that the same active firm is not assigned to two different bankrupt firms in different years. We end up with 1,032 matched (M) firms (one for each firm in our bankrupt sample), referred to as the matching sample.

\section{Variables}

We focus on several financial characteristics of the firm. On the liability side, we calculate the following indebtedness ratios: total liabilities, trade credit and total debt, all scaled by total assets (we refer to these ratios as TL_TA, TRADE_TA and DEBT_TA, respectively). We also look at two performance ratios: ROA - return on assets, calculated as income before taxes over total assets and RE_TA - the ratio of retained earnings over assets. The former reports the performance of the firm in the year prior to the filing and the latter reflects cumulative performance over time, i.e. firms that continually have been making losses will have low (or even negative) retained earnings.

Our main firm characteristic is the Z-score index constructed by Altman (1968) and updated by Altman (2000). It combines indebtedness, performance and liquidity measures and is commonly used as an indicator of financial distress. ${ }^{14}$ Based on Altman (2000) model estimated for non-publicly listed firms, the Z-score is given by:

Z-score $=0.717 *$ WC_TA $+0.847 *$ RE_TA $+3.107 *$ ROA $+0.420 *$ BVE_TL $+0.998 * S \_T A$

\footnotetext{
${ }^{13}$ Thus, if a bankrupt firm has data for year 0 , we use that year to find a match, but if it has financial data for year -1 or -2 , we use that year to find a match.

${ }^{14}$ Although recent research has challenged the use of accounting-based models such as Altman's in favor of Black-Scholes-Merton default probability models (Hillgeist et al., 2004), these models require stock market data. Unfortunately, most of the firms in our sample are non-listed firms. But even if we had stock market data, it remains to be settled whether the stock market in Colombia is efficient, as BSM default probability models assume. In any event, rather than using the Z-score to predict actual default, we use it a measure of firm financial health in order to assess the impact of the law.
} 
where, WC_TA is working capital (defined as current assets minus current liabilities over total assets), which is a measure of liquidity, ROA and RE_TA are describe above, BVE_TL is the ratio of book value of equity over total liabilities (a measure of indebtedness similar to the ratio of total liabilities to total assets) and S_TA is a ratio of total sales over total assets, which is used as another performance measure. We report the results for the composite Z-score, as it presents the overall measure of financial health. In most cases, since the sub-components of the Z-score behave similarly to the overall measure, the results are not reported (but are available on request). Finally, we use firm size (calculated as log of total assets) and firm age as controls.

To eliminate influential observations, we clean the data and remove outliers on all ratios. For ratios that are bounded from below by zero we only remove $1 \%$ of outliers on the top. For unbounded ratios we remove $1 \%$ on the top and the bottom of the distribution. ${ }^{15}$ For Z-score we remove outliers for each individual component before constructing the Z-score.

Table 1C reports basic summary statistics for our two samples of bankrupt firms and matched firms. As Table 1C shows, there is no difference in size and age between bankrupt and matched active firms.

\section{Descriptive Analysis}

In this section we present graphical evidence and univariate mean tests. Figure 2 plots kernel density distributions of the Z-score for R (reorganizations), L (liquidations) and $\mathrm{M}$ (matched active firms) before and after the change in the law. The vertical lines indicate the mean of each distribution. ${ }^{16}$ As Figure 2 shows, before the new law was introduced, R and L firms have very similar density distributions of Z-scores. Thus, firms filing for reorganization were not significantly different from the firms filing for liquidation. However, after the new law was introduced, the differences in the

\footnotetext{
${ }^{15}$ The exception is the return on assets, for which we remove $2 \%$ on the top and bottom ends because this variable has very long tails. In addition, for our time-series tests we remove outliers before and after constructing the matched sample.

${ }^{16}$ Although the model derives testable implications from the firm returns, we use the Z-score index as both are related. Return on assets (ROA) is a component of the overall Z-score index.
} 
distributions of $\mathrm{R}$ and $\mathrm{L}$ firms become more pronounced. Firms that liquidate are now clearly weaker relative to firms that reorganize. The whole distribution of L-firms shifted to the left with the new reorganization proceeding. In addition, the sample of matched active firms seems better off as its kernel density distribution has moved slightly to the right as compared to before the law. This presents the first evidence in support of Hypothesis B1.

We further examine the data using univariate mean tests of the variables described in Section IV.D. We first make pair-wise comparisons before and after the law (comparing $\mathrm{R}$ to $\mathrm{L}$ firms, $\mathrm{R}$ to $\mathrm{M}$ firms and $\mathrm{L}$ to $\mathrm{M}$ firms) and later we make before and after comparisons for each firm category. Tables 2A and 2B present the results.

Several patterns seem to emerge from the data. Not surprisingly, columns 5 and 6 of Table 2A show that $\mathrm{R}$ and $\mathrm{L}$ firms are significantly different from $\mathrm{M}$ firms: they have higher levels of debt (including bank debt and trade credit debt) and lower performance. Their overall financial health, measured by Z-score, is significantly weaker. In fact, active firms have on average positive Z-scores, while bankrupt firms have negative Zscores.

The most interesting result comes from the comparison between $\mathrm{R}$ and $\mathrm{L}$ before and after the law. In column 4 of Table $2 \mathrm{~A}$ we see that $\mathrm{R}$ firms are not significantly different from L firms before the law based on all six characteristics reported. However, from column 10 we see that $\mathrm{R}$ firms are significantly different from $\mathrm{L}$ firms after the law in five out of six characteristics. $\mathrm{R}$ firms have lower levels of total liabilities and trade credit obligations (and lower, but not statistically different levels of bank debt), better operating performance and higher overall Z-scores. These results confirm the graphical evidence of Figure 1 and provide additional evidence in support of Hypothesis B1.

Table 2B presents a different cut of the data. ${ }^{17}$ We again find that $\mathrm{L}$ firms are significantly worse after the law, having more debt and lower performance on all measures.

Finally, the duration of both liquidations and reorganizations is shorter after the new law. The difference is much more pronounced for reorganizations, from an average

\footnotetext{
${ }^{17}$ Although the means presented in this table are the same as those reported in Tables 2A, we compare here firms in the same category $(\mathrm{R}, \mathrm{L}$ and $\mathrm{M})$ before and after the law.
} 
of 34 months before the law to 12 months after. The difference for liquidations is more modest, with a change from 49 to 33 months. Recall however that duration can only be computed if both start and end dates are available. Since liquidations are usually long, our sample of finished liquidations is biased towards relatively short liquidations, especially after the law was introduced. We explore these differences more rigorously in Section VII.A.

\section{Regression Models}

In this section we present the econometric models used to test formally the assumptions and implications of the model described in Section III. All models compare reorganizations to liquidations before and after the law. In some specifications we include the sample of active firms.

\section{A. Duration of Reorganization}

We are interested in comparing the length of reorganization and liquidation cases before and after the law. The model we use is given by:

$$
\text { Duration }_{\mathrm{i}}=\beta_{1} \text { After }_{\mathrm{i}}+\beta_{2} \mathrm{R}_{\mathrm{i}}+\beta_{3} \mathrm{After}_{\mathrm{i}}^{*} \mathrm{R}_{\mathrm{i}}+\mathrm{X}_{\mathrm{i}} \gamma+\mathrm{e}_{\mathrm{i}}
$$

where After is a dummy equal to one if the filing date occurred after the new law, $\mathrm{R}$ is a dummy for firms filing for reorganization and vector $\mathrm{X}$ contains control variables like firm age and size.

Since half of the cases lack the end date, we assume that these cases are still unfinished. ${ }^{18}$ To properly account for these unfinished cases, we estimate a Cox proportional hazard model. Coefficients in the hazard model of Equation (2) that are larger than one and significant are to be interpreted as increasing the probability that cases will end. Therefore, variables associated with positive and significant coefficients will contribute to shorter durations. The coefficient $\beta_{1}$ shows the effect of the new law on

\footnotetext{
${ }^{18}$ The latest closing date in our data is August 3, 2004.
} 
the length of liquidations and therefore tests Hypothesis A2. It should be insignificant. Coefficient $\beta_{2}$ picks up the average difference in the duration between reorganization and liquidations before the law. Finally, $\beta_{3}$ picks up the length of reorganization as compared to liquidations after the law, and if Hypothesis A1 is correct, it should be positive and significant.

\section{B. Selection into Reorganization}

We estimate the following model combining the sample of bankrupt firms with the matched sample of active firms:

$$
\mathrm{Y}_{\mathrm{i}}=\beta_{1} \text { After }_{\mathrm{i}}+\beta_{2} \mathrm{~B}_{\mathrm{i}}+\beta_{3} \mathrm{After}_{\mathrm{i}} * \mathrm{~B}_{\mathrm{i}}+\beta_{4} \mathrm{~B}_{\mathrm{i}} * \mathrm{R}_{\mathrm{i}}+\beta_{5} \mathrm{After}_{\mathrm{i}} * \mathrm{~B}_{\mathrm{i}} * \mathrm{R}_{\mathrm{i}}+\mathrm{X}_{\mathrm{i}}{ }^{\prime} \gamma+\mathrm{e}_{\mathrm{i}}
$$

Here $\mathrm{Y}$ is one of the 6 dependent variables described in the previous section. In addition, $\mathrm{B}$ is a dummy for bankrupt firms (i.e. this dummy is equal to one for either $\mathrm{R}$ or L firms). We estimate these models by OLS, with heteroskedasticity-adjusted (White) standard errors. ${ }^{19}$

In this specification, $\beta_{1}$ shows the effect of the new law on active companies, $\beta_{2}$ shows the difference between bankrupt and active firms before the new law, $\beta_{3}$ shows the difference between bankrupt and active firms after the new law, $\beta_{4}$ shows the difference between $\mathrm{R}$ and $\mathrm{L}$ before the new law and $\beta_{5}$ shows the same difference after the new law. The coefficient of interest is $\beta_{5}$, the differential impact that the new law had on $\mathrm{R}$ versus $\mathrm{L}$ firms. $^{20}$

\section{Recovery after Reorganization}

Finally, we want to test whether the new law contributed to a faster recovery of reorganized firms. Naturally, we do not have any post filing data for liquidation cases.

\footnotetext{
${ }^{19}$ Note that B*R dummy is the same as R (in that R firms are included in B category), but we present it in the form of interaction to highlight that in this model we not only compare firms that reorganize (R) to those liquidate (L) among bankrupt firms but we also compare bankrupt firms to active firms.

${ }^{20}$ We also run two simpler models: the first compares bankrupt firms with active firms, i.e. in effect restricting the model to $\beta_{1}, \beta_{2}$ and $\beta_{3}$. The second model compares $\mathrm{R}$ to $\mathrm{L}$ firms, limiting the sample to include only bankrupt firms and thus only estimating $\beta_{1,} \beta_{4}$ and $\beta_{5}$. The results are similar and not shown but available upon request.
} 
Presumably these firms closed down or at least ceased to produce financial statements. Thus, this analysis is done only using reorganization cases. As already mentioned in Section IV.B, the sample for this analysis is smaller because of limited pre and post-law data availability.

Again, we focus on the Z-score as our main indicator. We expect to obtain something similar to a V-shape: a declining pattern before the filing as financial health deteriorates, and an increasing pattern (i.e. recovery) after the filing. We are interested to see whether this shape is affected by the law reform. Thus, we are interested in the slopes of time-trend variables. We define two time-trend variables: pre-filing period (Pretrend) and post-filing period (Posttrend). The Pretrend variable takes values $-1,-2,-3$ for years before the filing (and zero otherwise) and Posttrend variable takes value 1 in the year of filing, value of 2 in the first year after the filing and so on. ${ }^{21}$

Since the law was passed in 1999, the worst year of the crisis, firms filing after the law face an expansionary period while those that filed before the law faced the contraction. Thus, the effect of the overall macroeconomic conditions could be confounded with the effect of the new law that we are trying to capture. To remedy this problem, we assume that both bankrupt and active firms are equally affected by the macroeconomic conditions (an assumption that we are able to test in the next section). Our dependent variables are therefore defined as the difference in $\mathrm{Y}_{\text {it }}$ between bankrupt and matched active firm. The model is given by

$$
\begin{aligned}
\text { DiffY }_{\text {it }}= & \beta_{1} \text { After }_{\mathrm{i}}+\beta_{2} \text { Pretrend }_{\mathrm{it}}+\beta_{3} \text { Postrend }_{\mathrm{it}}+\beta_{4} \text { After }_{\mathrm{i}}{ }^{*} \text { Pretrend }_{\mathrm{it}}+ \\
& \beta_{5} \text { After }_{\mathrm{i}}{ }^{*} \text { Postrend }_{\mathrm{it}}+\mathrm{X}_{\mathrm{i}} \gamma+\mathrm{e}_{\mathrm{it} .} .
\end{aligned}
$$

In this model, $\beta_{2}$ shows the slope of DiffY $Y_{\text {it }}$ for years preceding the filing for firms that filed before the law. Analogously, $\beta_{3}$ shows the slope of DiffY $Y_{\text {it }}$ for the years after the filing again for firms that filed before the law. We expect $\beta_{2}$ to be negative (i.e. Z-scores decreasing over time) and $\beta_{3}$ to be positive if the firms recovers after the reorganization. The interaction of trends with the After dummy will show differences in pre and post

\footnotetext{
${ }^{21}$ We also experimented with defining post-trend starting in the year after the filing (instead of the year of the filing) and including separate dummies for the filing year and we obtained similar results.
} 
trend slopes for firms filing after the new law relatively to the slopes on these trends for firms filing under the old system.

\section{Regression Results}

\section{A. Duration of Reorganization}

Table 3 reports the hazard ratios from the Cox proportional hazard model in specification (2). In Column 1 the whole sample of firms for which we have duration data is used. Column 2 reports the same regression as Column 1 estimated on the sample of firms with financial data. The rest of columns include additional controls. ${ }^{22}$

We find that the AFTER coefficient is not significant in any specification. This implies that there are no differences in the length of liquidations before and after the law as Hypothesis A2 suggests. Second, reorganization proceedings seem to have shorter duration, especially after the reform. Before the reform, the marginal probability to finish the reorganization process (at any point in time) is 3 times that of the probability to finish liquidation. However, after the new law, this difference jumps to 14-25 times (depending on the specification). These results provide strong evidence that the law reform was very effective in shortening the length of reorganization, as Hypothesis A1 suggests.

The last specification explores the relationship between duration and Z-score at the time of filing. We find that while the length of liquidation does not depend on initial Z-score, healthier firms have shorter reorganizations. This effect is stronger (about twice as much) after the law. In terms of the equations depicted in Figure 1, this finding suggests that the expected net cash-flows for the firm that expects the maximum reorganization costs (bottom increasing line as $x_{1}$ goes from 0 to $\mathrm{p}$ ) has higher slope than expected cash-flow from 0 to $\mathrm{p}$ (upper increasing line as $x_{1}$ goes from 0 to $\mathrm{p}$ ). Before the law this effect is smaller than after the law.

\section{B. Selection into Reorganization}

\footnotetext{
${ }^{22}$ The number of observations is 1,896 . The total number of bankrupt firms is 1,924 as shown in Table $1 \mathrm{~A}$. A total of 28 observations are dropped either because the start date is missing or the end date comes before the start date.
} 
Table 4 reports our baseline results of the specification given in (3) which analyzes the financial conditions of firms at the time of filing. We focus our discussion on the Z-score results reported in Column 6. Bankrupt firms have significantly lower Zscores relative to active firms as the coefficient on the B dummy is negative and very significant, with a t-statistic of 9.7. This difference between bankrupt and active firms is even more pronounced after the new law as evidenced by the coefficient on After*B that is negative and significant. At the same time, the After coefficient suggests that active firms appear in better shape after the new law.

The coefficients of interest are the interactions $B * R$ and After*B*R. The first one is not significant, suggesting that under the old law there was no significant difference between firms filing for reorganization (i.e. R firms) and the firms filing for liquidation (i.e. $\mathrm{L}$ firms). However, the triple interaction is positive and significant at $1 \%$, suggesting that under the new law there is significant difference between $L$ and $R$ firms and that $R$ firms have higher Z-scores relative to L firms. In other words, after the new law R firms are significantly healthier relative to L firms. These results confirm those obtained in the graphical analysis and mean tests and support our Hypothesis B1.

We observe similar patterns in other dependent variables, although significance is somewhat weaker than the overall Z-score measure. The coefficient on the triple interaction is significant for ROA, RE_TA, and for LIA_TA (at 11\%). These results provide strong evidence for the effectiveness of the new law in separating healthier firms for reorganization.

We also compare the number of reorganizations that result in mandatory liquidations before and after the new law. Table $1 \mathrm{~A}$ shows that about 40 percent of firms filing for reorganization under the old law ended up in liquidation, while only about 26 percent did so under the new law. This difference is statistically significant with a tstatistic of close to 6. This result, validating Hypothesis B2, is further evidence that Law 550 contributed to the efficiency of the Colombian bankruptcy system.

\section{Recovery after Reorganization}

Finally, we study the time-series patterns in the Z-score for reorganizing firms. Note that our sample for this test contains firms with at least one pre-filing data point and 
at least one post-filing data point. Table 5A reports the average Z-scores for firms filing before and after the law and Figure 3 plots these means on a graph. We observe a clear pattern of declining Z-scores before filing, as expected. The financial health deteriorates as firms get closer to the verge of insolvency. This declining pre-filing pattern is observed for firms filing before and after the law. However, the recovery patterns are quite different in the two regimes. Before the law, no clear recovery is observed. Firms that filed for reorganization, if anything, are getting worse. In contrast, the recovery is very pronounced after the introduction of Law 550, with a clear upward trend in the years following the filing.

Table 5B presents the regression analysis corresponding to the graphical evidence just described. As expected, the Pretrend coefficient is negative for performance measures (ROA and RE_TA) and positive for leverage measures, suggesting that before the filing, leverage is increasing while performance is deteriorating. There is no significant difference in pre-trend patterns before and after the law. However, there is a significant difference in the Posttrend after the new law - the coefficient is positive and significant for the Z-score (but insignificant for individual measures). We consider the Zscore results to be the most important as this measure represents the overall index of financial health. These results suggest that after the new law, the reorganization process results in a more pronounced recovery in the years following the filing. This is in stark contrast to the post-filing pattern under the old law, which showed a continuous deterioration in firm performance. This evidence validates our Hypothesis C.

\section{Robustness to Crisis and Trend}

As mentioned in the introduction, the new law was introduced in the midst of a major financial crisis in late 1999. For our identification strategy to work, we need to make sure that the crisis did not have a differential effect on $\mathrm{R}$ relative to $\mathrm{L}$ firms. Otherwise, the effects we observe after the introduction of the law could also be due to the crisis itself. We test this by creating two crisis windows: year 1999 (the worst year of the crisis) and years 1998-2000, which span the worst crisis year. Fortunately, since our sample covers 1996-2003, we have several years outside of the crisis window on both 
sides (before and after the law), which allows us to test whether our results are influenced by the crisis.

Another potential concern with our results is that the effect that we attribute to the law reform could actually come from a gradual improvement in the efficiency of the bankruptcy system over time. To test that we create a linear time trend and use it in interactions in the same fashion as our After variable.

The crisis and trend regressions are presented in Table 6A for our duration results and Table 6B for Z-score.

In both tables, the first column reproduces the baseline specification for comparison: in Table 6A it is model 1 from Table 3 and in Table 6B it is model 7 from Table 4. Model 2 adds the trend and its interactions, Model 3 adds Crisis99 and its interactions, Model 4 adds Crisis98_00, Model 5 adds Crissis99 and trend and Model 6 adds Crisis98_00 and trend.

Our main interactions with After*R (Table 6A) and After*B and After*B*R (in Table 6B) remain significant in all the specifications, suggesting that the difference between the pre-reform and post-reform periods is not related to the financial crisis.

In Table 6B we see that Crisis99 dummy is significant and negative, suggesting that all firms were worse off during 1999, but Crisis98_00 is not significant, so the worst of the crisis is limited to 1999 . Neither Crisis*B, nor Crisis*B*R interactions are significant, suggesting that crisis did not have any differential effect on bankrupt firms (relative to active) or $\mathrm{R}$ firms relative to $\mathrm{L}$ firms. Since Crisis has the same effect on the whole distribution of firms, our identification strategy, that is, comparing bankrupt to active and $\mathrm{R}$ to $\mathrm{L}$, is valid.

It is important to reiterate that the results presented Section VII.C on recovery after reorganization are not confounded by the crisis because the dependent variables are defined as the difference between the bankrupt firms and the matched sample of active firms. From the results reported above we know that crisis did not have any differential effects on Z-scores of bankrupt relative to active firms. Thus, the difference in recovery is a result of the law because the crisis effect is differenced out.

\section{Conclusions}


This paper studies the relevance of reorganization costs for the efficiency of bankruptcy laws. We develop a simple model that predicts that in a regime with high costs, the law fails to achieve the efficient outcome of liquidating unviable businesses and reorganizing viable ones.

We test the model using Colombia as an example. In 1999, amidst a major crisis, the Colombian Congress replaced the existing corporate reorganization proceeding with a more streamlined procedure that limited negotiations to a maximum of eight months and stipulated that failure to reach an agreement would result in mandatory liquidation.

We use data from all filing firms in Colombia between 1996 and 2003, spanning the change in the reorganization law, to provide evidence that the new law increased the efficiency of the bankruptcy system in Colombia. We first show that indirect reorganization costs, as measured by the duration of the reorganization process, have significantly decreased after the reform. Second, we show that the pre-reform reorganization proceeding was so inefficient that it failed to separate economically viable firms from inefficient ones. In contrast, by substantially lowering reorganization costs, the new law succeeds in selecting healthier (and hence more viable) firms for reorganization. Finally, we show that the recovery of reorganized firms is significantly improved after the reform, as a result of lower costs and better selection of viable firms.

From a policy standpoint, this paper highlights the relevance of the design of bankruptcy laws. A reduction in the costs (both direct and indirect) associated with filing can contribute to the overall efficiency of the economy and should be a priority in the agenda for economic reforms. 


\section{Appendix 1. Background on Colombian Bankruptcy Law Reform. ${ }^{23}$}

In 1995, the Law 222 was enacted in an attempt to reduce the judiciary burden by allowing disputes among creditors and debtors to be resolved under the Superintendence of Companies. In addition, the superintendence, under the Ministry of Industry and Commerce, is in charge of supervising firms to prevent insolvency and fraud. The law established the procedures for both mandatory liquidation and restructuring under the Concordato proceedings. Voluntary liquidation was and is still regulated by the Commercial Code.

Before Law 222, mandatory liquidations were civil bankruptcy proceedings that lasted for many years because civil courts lacked capacity and specific business knowledge. Under Law 222, however, mandatory liquidation proceedings are still lengthy, usually taking more than three years to resolve. The length of the proceedings in practice implies that a substantial part of the assets of the debtor are lost either because they loose value over time (indirect cost) or are spent towards paying the fees and expenses of the liquidation (direct costs). As a result, the perception is that mandatory liquidation is very inefficient.

Although more authority was given to the superintendence, the Concordato proceedings under Law 222 still suffered from being excessively long. In essence, too much leverage was given to the debtor in the negotiations with creditors. Delays were favorable to debtors as they allowed them to suspend the debt service, and also granted protection by the stay against execution actions commenced by creditors (Tamayo et al., 2002).

This situation resulted in many private agreements (workouts), mainly between the financial institutions and the debtor, outside the scope of the Concordato. These agreements were typically used to restructure and reschedule the debtor's obligations but are considered onerous by both parties as it is difficult to reach agreements. In Colombia, they are regulated by the general Civil Law under the principle of freedom of will of all the parties involved.

\footnotetext{
23 This Section draws from Urrutia (2004).
} 
Starting in 1998 after decades of consistent growth, the Colombian economy suffered a major recession. The severity of the crisis forced the government to propose several bills to Congress. One of them replaced the sections of Law 222 that concerned the reorganization proceeding and became known as Law 550 after it was approved by Congress in December of 1999.

The Law 550 applies to all types of companies, regardless of their organizational nature, except for financial institutions. The entity responsible for conducting the proceedings is the Superintendence of Companies ${ }^{24}$ as was the case under Law 222, or the relevant superintendence in charge of its supervision.

The Acuerdo, or reorganization proceeding under Law 550, is divided into two major phases during which the management of the bankrupt firm remains in charge. The first consists of the determination of votes and claims according to the parties' stake in the firm. In the second, the negotiation and voting of the reorganization plan takes place. Each phase may last for a maximum of 4 months and failure to meet the deadline results in mandatory liquidation.

After a reorganization case was filed under old Law 222, the superintendence appointed a controller and a provisional committee of creditors. Past experience showed that the creditors committee and the controller interfered many times with the task of managing the company. Therefore, Law 550 eliminates the need to appoint a creditors committee and the controller for the proceedings. Instead, the Law 550 creates the figure of the promoter, an independent person also appointed by the relevant superintendence. ${ }^{25}$ The promoter gathers and analyzes business and financial information of the debtor, compiles a complete list of creditors, facilitates the negotiations among the creditors, conceives the restructuring plan and coordinates the voting process for approval of the restructuring agreement. The promoter participates actively in the negotiations and determines the voting rights among the parties involved. For his or her services, the

\footnotetext{
${ }^{24}$ Although the proceedings are administrative rather than judicial, Law 550 grants to the superintendence the power and authority to make certain decisions which have the force of a final judgment.

${ }^{25}$ Sometimes, creditors and debtor may suggest a candidate for consideration, and practice has shown that when this happens, the Superintendent accepts the candidate suggested.
} 
promoter is paid a success fee, thus having a stake in ensuring that an agreement will be reached.

Under Law 222, any Concordato agreement had to be approved by the debtor. In practice, this implied that the debtor effectively had the veto power, regardless of his or her stake in the firm. To solve this problem, Law 550 establishes that shareholders of the debtor company are "internal creditors", one of the five different classes ${ }^{26}$ of creditors among which voting rights are distributed according to their claims to the firm.

The number of votes needed to approve a reorganization plan also changed. Under Law 222, the Concordato required a majority vote of 75 percent of all creditors recognized in the proceedings, which many times became an insurmountable obstacle due to lack of interest of certain creditors which simply neglected to participate in the proceedings. In contrast, under Law 550 the Acuerdo only requires a 51 percent majority of the eligible votes of creditors to approve the restructuring agreement.

Although Law 550 is an important improvement with respect to the previous law, a report commissioned by the superintendence shows some dissatisfaction among firms that filed for reorganization with regards to access to fresh credit. It thus seems that banks are still reluctant to give credit to firms under reorganization.

In addition, several practitioners in Colombia have pointed out some improvements that if introduced could result in lower coordination costs among creditors and debtors and therefore lead to faster agreements. Currently under Law 550, once the reorganization plan is approved with the required majority of creditors, it is binding by all parties. Dissenting creditors may file lawsuits before the relevant superintendence but this is problematic as small creditors may object to the plan delaying its implementation although their claim is relatively small.

Law 550 was to be in force only for a five year term. The government and Congress approved a bill that will extend the application of Law 550 until December 2006, while Congress discusses the new insolvency draft law.

\footnotetext{
${ }^{26}$ Claims are classified by the law both for purposes of voting and priority of claims. There are five different classes of creditors: Internal creditors, External creditors, Employees and retired employees, Governmental entities, Financial institutions. For purposes of priority the classification is that of the Civil Code.
} 


\section{REFERENCES}

Aghion, P., O. Hart and J. Moore, 1992, The economics of bankruptcy reform, Journal of Law and Economics 8, 523-546.

Alderson, M.J. and B.L. Betker, 1995, Liquidation costs and capital structure, Journal of Financial Economics 39, p. 45-69.

Altman, E.I., 1968, Finanical ratios, discriminant analysis and the prediction of corporate bankruptcy, Journal of Finance 23, 589-609.

1984, A further empirical investigation of the bankruptcy cost question, Journal of Finance 39, 1067-1089. 2000, Predicting financial distress of companies: Revisiting the Z-score and

Zeta Models, Stern School of Business, New York University, mimeo.

Baird, D. G, 1986, The uneasy case for corporate reorganizations, Journal of Legal Studies 15, 125-147.

Bris, A., I. Welch and N. Zhu, 2005, The Costs of Bankruptcy: Chapter 7 Liquidation vs. Chapter 11 Reorganization, Journal of Finance (Forthcoming)

Bulow, J.I. and J.B. Shoven, 1978, The bankruptcy decision, The Bell Journal of Economics 9, 437-456.

Claessens, S., Djankov, S., Mody, A., and Stiglitz, J. 2001, Resolution of Financial Distress: An international Perspective on the Design of Bankruptcy Laws, An overview and Chapter 1.

and Klapper, L. F., 2003, Bankruptcy around the world: explanations of its relative use, The World Bank, Policy Research Working Paper Series, 1-42.

Davydenko, S and J. Franks, 2005, Do Bankruptcy Codes Matter? A Study of Defaults in France, Germany and the UK, Finance Working paper 89/2005, European Corporate Governance Institute.

Franks J.R. and G. Loranth, 2005, "A Study of Inefficient Going Concerns in Bankruptcy.” CEPR Discussion Paper 5035, Centre for Economic Policy Research, London. and Torous, W.N., 1989, An empirical investigation of U.S. firms in reorganization, Journal of Finance 44, 747-769.

Hart, O., 2000 Different Approaches to Bankruptcy, NBER working paper 7921.

Hillegeist, S.A, Keating, E.K., Cram, D.P., and Lundstedt, K.G., 2004, Assessing the probability of bankruptcy, Review of Accounting Studies 9, 5-34.

Hotchkiss, Edith S., 1995, Post-bankruptcy performance and management turnover, Journal of Finance 50, 3-21.

Kahl, M., 2002, Economics distress, financial distress, and dynamic liquidation, The Journal of Finance 57, 135-168.

Gertner, R. and D. Scharfstein, 1991, A theory of workouts and the effects of reorganization law, Journal of Finance 4, 1189-1221.

Maksimovic, V. and M.G. Phillips, 1998, Asset efficiency and reallocation decisions of bankrupt firms, Journal of Finance 53, 1495-1532.

Milgrom, P., 1981, Good News and bad news: representation theorems and applications, The Bell Journal of Economics 12, 380-391.

Shleifer, A., and Vishny, R.W., 1992, Liquidation values, and debt capacity: A market equilibrium approach, Journal of Finance 47, 1343-1366.

Smith, D.C., and Strömberg, P., 2004, Maximizing the value of distressed assets: Bankruptcy law and the efficient reorganization of firms, prepared for the World Bank conference on Systematic Financial Distress.

Stromberg, P., 2000, Conflicts of Interest and Market Illiquidity in Bankruptcy Auctions: Theory and Tests, Journal of Finance 55, 2641-2692. 
Tamayo, D. F. Visbal and M. Nuñez, 2002, El Sesgo Anti-Acreedor en los Contratos de Garantía y en los Procesos de Reestructuración de la Ley 550 de 1999. In González Muñoz, C., A. García and A. Carrasquillo, El Sector Financiero de Cara al Siglo XXI, ANIF, Bogotá.

Thorburn, K.S., 2000, Bankruptcy auctions: Costs, debt recovery and firm survival, Journal of Financial Economics 58, 337-368.

Uribe, J.D. and H. Vargas, 2002, Financial Reform, Crisis and Consolidation in Colobmia, Borradores de Economía 204, Banco de la República, Colombia.

Urrutia, C, 2004 Insolvency Reform in Colombia, prepared for the World Bank, Brigard \& Urrutia, Bogotá, Colombia.

Urrutia, M and Zárate, J.P 2001, La Crisis Financiera de Fin de Siglo, Banco de la República, Colombia.

White, M.J., 1994, Corporate bankruptcy as a filtering device: Chapter 11 reorganizations and out-of-court debt restructurings, Journal of Law, Economics, and Organization 10, 268-295.

$3,129-151$ , 1989, The corporate bankruptcy decision, Journal of Economic Perspectives

Weiss, Lawrence, A., 1990, Bankruptcy resolution: Direct costs and violation of priority of claims, Journal of Financial Economics 27, 285-314. , and K.H. Wruck, 1998, Information problems, conflicts of interest and asset stripping: Chapter 11's failure in the case of Eastern Airlines, Journal of Financial Economics 48, 55-97.

World Bank, 2006, Closing a business, Doing business in 2006: Creating Jobs, 67-76. Growth, 67-78. , 2005, Closing a business, Doing business in 2005: Removing Obstacles to , 2004, Closing a business, Doing business in 2004: Understanding Regulations, 71-103, 112-114. 


\section{Table 1. Data availability}

The first four columns report the number of firms with existing bankruptcy data. The last three columns report the number of firms with existing bankruptcy and financial data and in parenthesis the total number of years of data for these firms. The first and fifth column report the total number of observations, the third and sixth the number of firms that filed before 2000, under the old law, and the fourth and seventh the number of firms that filed after 2000 under the new law. The second column reports the number of reorganizations that ended in mandatory liquidation.

\section{Panel A. Number of Observations by Bankruptcy Case}

\begin{tabular}{|c|c|c|c|c|c|c|c|c|}
\hline \multirow[b]{2}{*}{ Cases } & \multirow[b]{2}{*}{ Description } & \multicolumn{4}{|c|}{$\frac{\text { Bankruptcy Data }}{\text { Number of firms }}$} & \multicolumn{3}{|c|}{$\begin{array}{c}\frac{\text { Financial Data }}{\text { Number of firms }} \\
\text { (Number of firm - year obs.) }\end{array}$} \\
\hline & & Total & $\begin{array}{l}\text { Mandatory } \\
\text { Liquidation }\end{array}$ & Before & After & Total & Before & After \\
\hline ACUERDOS & Reorganization under Law 550 & 780 & 184 & 0 & 780 & $\begin{array}{c}561 \\
(2,651)\end{array}$ & $\begin{array}{c}0 \\
(0)\end{array}$ & $\begin{array}{c}561 \\
(2,651)\end{array}$ \\
\hline CONCORDATOS & Reorganization under Law 222 & 590 & 214 & 590 & 0 & $\begin{array}{c}441 \\
(2,152)\end{array}$ & $\begin{array}{c}441 \\
(2,152)\end{array}$ & $\begin{array}{c}0 \\
(0)\end{array}$ \\
\hline LIQUIDACIONES & Liquidation under Law 222 & 554 & - & 283 & 271 & $\begin{array}{c}199 \\
(547)\end{array}$ & $\begin{array}{c}88 \\
(158)\end{array}$ & $\begin{array}{c}111 \\
(389)\end{array}$ \\
\hline TOTAL BANKRUPT FIRMS & Firms that filed for bankruptcy & 1,924 & 398 & 873 & 1,051 & $\begin{array}{c}1,201 \\
(5,350)\end{array}$ & $\begin{array}{c}529 \\
(2,310)\end{array}$ & $\begin{array}{c}672 \\
(3,040)\end{array}$ \\
\hline TOTAL ACTIVE FIRMS & Firms that never filed bankruptcy & & & & & $\begin{array}{c}13,891 \\
(68,298)\end{array}$ & $(35,054)$ & $(33,244)$ \\
\hline
\end{tabular}


Panel B. Number of Observations by Sector

\begin{tabular}{|c|c|c|c|c|}
\hline \multirow{2}{*}{ Main Sectors } & \multicolumn{2}{|c|}{ Bankrupt } & \multicolumn{2}{|c|}{ Active } \\
\hline & No. of firms & Percent & No. of firms & Percent \\
\hline $\begin{array}{l}\text { Agriculture, hunting, forestry, and } \\
\text { fishing }\end{array}$ & 83 & $6.9 \%$ & 1,049 & $7.6 \%$ \\
\hline Mining and quarrying & 19 & $1.6 \%$ & 406 & $2.9 \%$ \\
\hline Manufacturing & 478 & $39.8 \%$ & 2,746 & $19.8 \%$ \\
\hline Construction & 147 & $12.2 \%$ & 1,742 & $12.5 \%$ \\
\hline Wholesale and retail trade & 281 & $23.4 \%$ & 3,137 & $22.6 \%$ \\
\hline Hotels and restaurants & 40 & $3.3 \%$ & 192 & $1.4 \%$ \\
\hline $\begin{array}{l}\text { Transport, storage and } \\
\text { communications }\end{array}$ & 36 & $3.0 \%$ & 777 & $5.6 \%$ \\
\hline Financial intermediation & 11 & $0.9 \%$ & 1,399 & $10.1 \%$ \\
\hline $\begin{array}{l}\text { Real estate, renting and business } \\
\text { activities }\end{array}$ & 62 & $5.2 \%$ & 2,011 & $14.5 \%$ \\
\hline Other & 44 & $3.7 \%$ & 431 & $3.1 \%$ \\
\hline Total & 1,201 & $100.0 \%$ & 13,890 & $100.0 \%$ \\
\hline
\end{tabular}




\section{Panel C. Summary statistics}

LIA_A is measured as total liabilities / total assets, TRADE_A is trade credits / assets, DEBT_A is total debts / total assets, ROA (return on assets) is income before taxes over assets, RE_TA is retained earnings / total assets. Z-score is calculated using Altman's Z-score model: Z-score $=0.717 *$ WC_TA $+0.847 *$ RE_TA + 3.107*ROA $1+0.420 * B V E \_T L+0.998 * S \_T A$. In this model, WC_TA is working capital / total assets, BVE_TL is book value of equity / book value of total liabilities, and S_TA is sales / total assets. DURATION is the length of the bankruptcy procedure computed from the starting and ending dates, measured in months. SIZE is log of total assets and AGE is log of year of incorporation. Column starting with $\mathbf{p}$ reports the percentile.

\begin{tabular}{|c|c|c|c|c|c|c|c|c|c|c|}
\hline \multicolumn{11}{|c|}{ Bankrupt Firms } \\
\hline Variable & N. Obs & Mean & St. Dev & Min & p5 & p25 & p50 & p75 & p95 & Max \\
\hline TRĀDE_A & 1014 & 0.39 & 0.34 & 0.00 & 0.05 & 0.17 & 0.30 & 0.50 & 1.04 & 2.49 \\
\hline ROA & 999 & -0.25 & 0.27 & -1.32 & -0.85 & -0.35 & -0.16 & -0.06 & 0.01 & 0.19 \\
\hline RE_TA & 1002 & -0.48 & 0.58 & -3.59 & -1.78 & -0.62 & -0.32 & -0.11 & 0.03 & 0.26 \\
\hline Z-score & 1018 & -0.61 & 2.19 & -12.98 & -4.29 & -1.33 & -0.24 & 0.51 & 1.70 & 15.68 \\
\hline WC_TA & 1011 & -0.22 & 0.49 & -2.57 & -1.16 & -0.43 & -0.12 & 0.07 & 0.39 & 0.87 \\
\hline S_TA & 1031 & 0.71 & 0.75 & 0.00 & 0.00 & 0.19 & 0.52 & 0.95 & 2.11 & 5.83 \\
\hline SIZE & 1022 & 14.84 & 1.42 & 8.69 & 12.68 & 13.93 & 14.80 & 15.80 & 17.14 & 18.79 \\
\hline AGE & 1008 & 2.65 & 0.79 & 0.00 & 1.10 & 2.20 & 2.77 & 3.22 & 3.76 & 4.04 \\
\hline DURATION & 740 & 19.38 & 15.55 & 0.00 & 6.20 & 8.05 & 12.70 & 26.65 & 53.95 & 74.70 \\
\hline \multicolumn{11}{|c|}{ Matched sample of Active Firms } \\
\hline DEBT_馬 & 1030 & 0.13 & 0.16 & 0.00 & 0.00 & 0.00 & 0.07 & 0.19 & 0.44 & 0.98 \\
\hline $\mathrm{ROA}^{-}$ & 985 & 0.00 & 0.14 & -1.16 & -0.23 & -0.04 & 0.02 & 0.07 & 0.17 & 0.26 \\
\hline RE_TA & 982 & -0.08 & 0.40 & -3.72 & -0.65 & -0.08 & 0.02 & 0.08 & 0.20 & 0.27 \\
\hline Z-score & 1005 & 2.41 & 2.66 & -9.56 & -0.51 & 1.07 & 2.05 & 3.26 & 7.64 & 16.55 \\
\hline WC_TA & 1013 & 0.19 & 0.31 & -1.54 & -0.29 & 0.01 & 0.18 & 0.38 & 0.68 & 0.92 \\
\hline RE_TA & 982 & -0.08 & 0.40 & -3.72 & -0.65 & -0.08 & 0.02 & 0.08 & 0.20 & 0.27 \\
\hline BVE_TL & 990 & 2.20 & 3.21 & -0.59 & 0.04 & 0.47 & 1.04 & 2.35 & 9.63 & 20.31 \\
\hline S_TA & 1013 & 1.06 & 0.98 & 0.00 & 0.00 & 0.30 & 0.86 & 1.50 & 3.02 & 5.95 \\
\hline SIZE & 1022 & 14.84 & 1.41 & 8.56 & 12.70 & 13.94 & 14.80 & 15.79 & 17.13 & 18.78 \\
\hline AGE & 1003 & 2.62 & 0.81 & 0.00 & 1.10 & 2.20 & 2.77 & 3.22 & 3.69 & 4.04 \\
\hline
\end{tabular}




\section{Table 2. Mean tests}

$\mathbf{R}$ firms are those that filed for reorganization, $\mathbf{L}$ firms filed for liquidation, and $\mathbf{M}$ is the matched sample of active firms. We mark the difference with ${ }^{* * *}, * *$ or $*$ to indicate significance at the 1,5 or 10 percent level, respectively. See Table 1 for definition of variables.

Panel A. Pair wise comparison of $R, L$, and $M$ firms before and after the law

\begin{tabular}{|c|c|c|c|c|c|c|c|c|c|c|c|c|}
\hline \multirow[b]{2}{*}{ Variables } & \multicolumn{6}{|c|}{ Before the Law } & \multicolumn{6}{|c|}{ After the Law } \\
\hline & $\mathbf{R}$ & $\mathbf{L}$ & M & R vs L & R vs $M$ & L vs $M$ & $\mathbf{R}$ & $\mathbf{L}$ & M & R vs L & R vs $M$ & L vs M \\
\hline LIA_A & 0.9 & 0.92 & 0.5 & -0.02 & $0.40^{\star \star \star}$ & $0.42^{\star \star \star}$ & 0.96 & 1.27 & 0.48 & $-0.31^{\star \star \star}$ & $0.48^{\star \star \star}$ & $0.79 * * \star$ \\
\hline TRADE_A & 0.36 & 0.35 & 0.26 & 0.01 & $0.10^{\star \star \star}$ & $0.09 * \star \star$ & 0.42 & 0.51 & 0.26 & $-0.09 *$ & $0.16^{\star \star \star}$ & $0.25^{\star \star \star}$ \\
\hline DEBT_A & 0.38 & 0.36 & 0.14 & 0.02 & $0.24^{\star \star \star}$ & $0.22^{\star \star \star}$ & 0.3 & 0.33 & 0.11 & -0.03 & 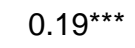 & $0.22^{\star \star \star}$ \\
\hline ROA1 & -0.27 & -0.23 & -0.01 & -0.04 & $-0.26^{\star \star \star}$ & $-0.22^{\star \star \star}$ & -0.23 & -0.34 & 0.01 & $0.11^{\star \star *}$ & $-0.24^{\star \star \star}$ & $-0.35^{\star \star \star}$ \\
\hline RE_TA & -0.42 & -0.42 & -0.06 & 0 & $-0.36^{\star \star \star}$ & $-0.36^{\star \star \star}$ & -0.53 & -0.81 & -0.1 & $0.28^{\star \star \star}$ & $-0.43^{\star \star \star}$ & $-0.71^{\star \star \star}$ \\
\hline Z-score & -0.61 & -0.34 & 2.23 & -0.27 & $-2.84^{\star \star \star}$ & $-2.57^{\star \star \star}$ & -0.56 & -2.07 & 2.6 & $1.51^{\star \star \star}$ & $-3.16^{\star \star *}$ & $-4.67^{\star \star \star}$ \\
\hline N. Obs & 388 & 130 & 518 & & & & 473 & 41 & 514 & & & \\
\hline DURATION & 34.1 & 48.62 & & $-14.52^{\star \star \star}$ & & & 11.71 & 33.2 & & $-21.49 * * *$ & & \\
\hline N. Obs & 590 & 283 & & & & & 780 & 271 & & & & \\
\hline
\end{tabular}

Panel B. Before and after the law comparison by firm category

\begin{tabular}{|c|c|c|c|c|c|c|c|c|c|}
\hline Variables & Before & $\begin{array}{r}\mathbf{R} \\
\text { After } \\
\end{array}$ & Difference & Before & $\begin{array}{c}\text { L } \\
\text { After }\end{array}$ & Difference & Before & $\begin{array}{c}\text { M } \\
\text { After }\end{array}$ & Difference \\
\hline LIA_A & 0.9 & 0.96 & $-0.06^{\star \star}$ & 0.92 & 1.27 & $-0.35^{\star \star \star}$ & 0.5 & 0.48 & 0.02 \\
\hline TRADE_A & 0.36 & 0.42 & $-0.06^{\star \star \star}$ & 0.35 & 0.51 & $-0.16^{\star \star \star}$ & 0.26 & 0.26 & 0 \\
\hline DEBT_A & 0.38 & 0.3 & $0.08^{\star \star \star}$ & 0.36 & 0.33 & 0.03 & 0.14 & 0.11 & $0.03^{\star \star \star}$ \\
\hline ROA1 & -0.27 & -0.23 & $-0.04^{\star \star}$ & -0.23 & -0.34 & $0.11^{\star \star}$ & -0.01 & 0.01 & $-0.02^{\star}$ \\
\hline RE_TA & -0.42 & -0.53 & $0.11^{\star \star \star}$ & -0.42 & -0.81 & 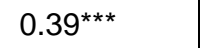 & -0.06 & -0.1 & $0.04^{\star \star}$ \\
\hline Z-score & -0.61 & -0.56 & -0.05 & -0.34 & -2.07 & $1.73^{\star \star \star}$ & 2.23 & 2.6 & $-0.37^{\star \star}$ \\
\hline N. Obs & 388 & 473 & & 130 & 41 & & 518 & 514 & \\
\hline DURATION & 34.1 & 11.71 & $22.39 * \star \star$ & 48.62 & 33.2 & $15.42^{\star \star \star}$ & & & \\
\hline N. Obs & 590 & 780 & & 283 & 271 & & & & \\
\hline
\end{tabular}


Table 3: Duration of Reorganization

The dependent variable is DURATION measured as the length of each bankruptcy procedure from the starting and the ending dates, calculated in months. AFTER is a dummy variable equal to 1 for firms filing after the new law and $\mathbf{R}$ is a dummy variable equal to 1 for firms filing for reorganization. The rest of variables are defined in Table 1C. The model estimated is the Cox proportional hazard. Reported are hazard ratios and absolute values of z-statistics in brackets. ${ }^{* * *}$, ${ }^{* *}$ and $*$ represent significance at the 1 , 5, and 10 percent level.

\begin{tabular}{|c|c|c|c|c|c|c|c|}
\hline & $\begin{array}{c}\text { (1) } \\
\text { Baseline }\end{array}$ & $\begin{array}{c}(2) \\
\text { Baseline on } \\
\text { small } \\
\text { sample } \\
\end{array}$ & $\begin{array}{c}\text { (3) } \\
+ \text { Industry }\end{array}$ & $\begin{array}{r}(4) \\
+ \text { SIZE }\end{array}$ & $\begin{array}{c}\text { (5) } \\
+ \text { Zscore }\end{array}$ & $\begin{array}{c}(6) \\
+ \text { SIZE \& } \\
\text { Zscore }\end{array}$ & $\begin{array}{c}\text { (7) } \\
+ \text { SIZE, Zscore, } \\
\text { \& Interaction } \\
\text { terms }\end{array}$ \\
\hline AFTER & {$[0.77]$} & {$[1.17]$} & {$[1.22]$} & {$[1.20]$} & {$[1.00]$} & {$[0.98]$} & [1.25] \\
\hline \multirow[t]{2}{*}{$\mathbf{R}$} & $3.083^{\star \star *}$ & $3.163^{\star * *}$ & $3.167^{\star * \star}$ & $3.090^{* * *}$ & $3.218^{\star * *}$ & $3.143^{\star * *}$ & $2.748^{\star \star \star}$ \\
\hline & {$[8.30]$} & {$[4.94]$} & {$[4.94]$} & {$[4.83]$} & {$[4.89]$} & {$[4.78]$} & {$[4.20]$} \\
\hline AFTER*R & {$[10.58]$} & {$[6.47]$} & {$[6.56]$} & {$[6.60]$} & {$[6.31]$} & {$[6.34]$} & {$[6.27]$} \\
\hline Industry dummy & No & No & Yes & Yes & Yes & Yes & Yes \\
\hline \multirow[t]{2}{*}{ Z-score } & & & & & 0.998 & 1 & 1.169 \\
\hline & & & & & {$[0.09]$} & {$[0.02]$} & [1.13] \\
\hline \multirow[t]{2}{*}{ SIZE } & & & & 0.991 & & 0.986 & 0.983 \\
\hline & & & & [0.39] & & {$[0.53]$} & {$[0.67]$} \\
\hline AFTER*Z-score & & & & & & & [1.43] \\
\hline \multirow[t]{2}{*}{ Z-score*R } & & & & & & & $0.744^{\star *}$ \\
\hline & & & & & & & [2.10] \\
\hline \multirow[t]{2}{*}{ AFTER*R*Z-score } & & & & & & & $1.602^{\star *}$ \\
\hline & & & & & & & {$[2.50]$} \\
\hline N. Obs & 1896 & 1193 & 1193 & 1174 & 1155 & 1138 & 1138 \\
\hline
\end{tabular}




\section{Table 4: Selection into Reorganization}

The variables are defined in Table $1 \mathrm{C}$ and Table 3. B is a dummy that equals 1 for firms that filed any bankruptcy procedure (reorganization or liquidation). Absolute values of heteroskedasticity-adjusted (White) t-statistics are in brackets. ***, ** and * represent significance at the 1,5 , and 10 percent level.

\begin{tabular}{|c|c|c|c|c|c|c|}
\hline & (1) & (2) & (3) & (4) & (5) & (6) \\
\hline $\begin{array}{l}\text { Dependent } \\
\text { Variable: }\end{array}$ & LIA_A & TRADE_A & DEBT_A & ROA1 & RE_TA & Zscore \\
\hline After & $\begin{array}{l}-0.005 \\
{[0.24]}\end{array}$ & $\begin{array}{l}0.008 \\
{[0.51]}\end{array}$ & $\begin{array}{c}-0.021^{\star *} \\
{[2.20]}\end{array}$ & $\begin{array}{l}0.006 \\
{[0.61]}\end{array}$ & $\begin{array}{c}-0.058^{\star *} \\
{[2.14]}\end{array}$ & $\begin{array}{l}0.323^{\star} \\
{[1.90]}\end{array}$ \\
\hline B & $\begin{array}{c}0.418^{\star \star \star} \\
{[8.89]}\end{array}$ & $\begin{array}{c}0.090^{\star \star \star \star} \\
{[2.72]}\end{array}$ & $\begin{array}{c}0.215^{\star \star \star} \\
{[8.43]}\end{array}$ & $\begin{array}{c}-0.227^{\star \star \star} \\
{[9.13]}\end{array}$ & $\begin{array}{c}-0.365^{\star \star \star} \\
{[6.61]}\end{array}$ & $\begin{array}{c}-2.567^{\star \star \star \star} \\
{[9.69]}\end{array}$ \\
\hline After*B & $\begin{array}{c}0.353^{\star \star} \\
{[2.37]}\end{array}$ & $\begin{array}{c}0.130 * \star \\
{[2.36]}\end{array}$ & $\begin{array}{l}0.008 \\
{[0.13]}\end{array}$ & $\begin{array}{c}-0.111^{*} \\
{[1.87]}\end{array}$ & $\begin{array}{c}-0.354^{\star \star} \\
{[2.48]}\end{array}$ & $\begin{array}{c}-2.125^{\star \star \star} \\
{[3.62]}\end{array}$ \\
\hline$B^{*} R$ & $\begin{array}{l}-0.034 \\
{[0.68]}\end{array}$ & $\begin{array}{l}-0.004 \\
{[0.11]}\end{array}$ & $\begin{array}{l}0.025 \\
{[0.90]}\end{array}$ & $\begin{array}{l}-0.028 \\
{[1.04]}\end{array}$ & $\begin{array}{c}0.01 \\
{[0.17]}\end{array}$ & $\begin{array}{l}-0.246 \\
{[0.94]}\end{array}$ \\
\hline After* $B^{\star} R$ & $\begin{array}{c}-0.246 \\
{[1.63]}\end{array}$ & $\begin{array}{c}-0.043 \\
{[0.74]}\end{array}$ & $\begin{array}{l}-0.056 \\
{[0.88]}\end{array}$ & $\begin{array}{c}0.129 * * \\
{[2.10]}\end{array}$ & $\begin{array}{l}0.274^{\star} \\
{[1.89]}\end{array}$ & $\begin{array}{c}1.772^{\star \star \star} \\
{[3.06]}\end{array}$ \\
\hline SIZE & $\begin{array}{c}-0.057^{\star \star \star} \\
{[6.68]}\end{array}$ & $\begin{array}{c}-0.051^{\star \star \star} \\
{[8.81]}\end{array}$ & $\begin{array}{c}0.021^{\star \star \star} \\
{[5.73]}\end{array}$ & $\begin{array}{c}0.026^{\star \star \star} \\
{[6.59]}\end{array}$ & $\begin{array}{c}0.073^{\star \star \star} \\
{[7.30]}\end{array}$ & $\begin{array}{c}0.180^{\star \star \star *} \\
{[3.50]}\end{array}$ \\
\hline AGE & $\begin{array}{c}-0.054^{\star \star \star} \\
{[4.33]}\end{array}$ & $\begin{array}{c}-0.035^{\star * *} \\
{[4.11]}\end{array}$ & $\begin{array}{c}-0.020^{\star \star *} \\
{[3.16]}\end{array}$ & $\begin{array}{l}0.003 \\
{[0.45]}\end{array}$ & $\begin{array}{c}-0.008 \\
{[0.56]}\end{array}$ & $\begin{array}{l}0.018 \\
{[0.25]}\end{array}$ \\
\hline Constant & $\begin{array}{c}1.393^{\star * \star} \\
{[8.10]}\end{array}$ & $\begin{array}{c}1.009^{* \star *} \\
{[9.47]}\end{array}$ & $\begin{array}{r}-0.103 \\
{[1.10]} \\
\end{array}$ & $\begin{array}{c}-0.398^{\star \star *} \\
{[5.20]}\end{array}$ & $\begin{array}{c}-1.092^{\star \star \star} \\
{[6.02]}\end{array}$ & $\begin{array}{l}-0.489 \\
{[0.46]}\end{array}$ \\
\hline $\begin{array}{c}\text { N. Obs } \\
\text { R-squared }\end{array}$ & $\begin{array}{c}1992 \\
0.28\end{array}$ & $\begin{array}{c}1992 \\
0.16\end{array}$ & $\begin{array}{l}1991 \\
0.24\end{array}$ & $\begin{array}{c}1934 \\
0.28\end{array}$ & $\begin{array}{c}1932 \\
0.19\end{array}$ & $\begin{array}{c}1974 \\
0.3\end{array}$ \\
\hline
\end{tabular}


Table 5: Recovery after Reorganization

Panel A. Mean Difference of Zscore between bankrupt and active firms

\begin{tabular}{cccccccc}
\hline \hline & B - 3yr & B - 2yr & B - 1yr & B year & B +1yr & B +2yr & B +3yr \\
\hline Before & -0.93 & -1.41 & -2.02 & -2.57 & -2.50 & -2.95 & 85 \\
No. of obs & 38 & 72 & 100 & -2.17 & -2.55 & -2.31 & -2.17 \\
After & -1.34 & -1.71 & 183 & 189 & 167 & -1.42 \\
No. of obs & 152 & 167 & 55 & 115 \\
\hline \hline
\end{tabular}

Panel B. Regression analysis.

Pretrend is a variable which takes values of $-1,-2,-3$ for years before the filing and Postrend is one which takes value of 1 in the year of filing, value of 2 in the first year after the filing and so on. Pretrend*AFTER and Postrend*AFTER are the interaction terms of Pretrend and Postrend with AFTER dummy. See Table 1 Panel C for definitions of other variables.

\begin{tabular}{|c|c|c|c|c|c|c|}
\hline & $\begin{array}{c}\text { (1) } \\
\text { difLIA_A }\end{array}$ & $\begin{array}{c}\text { (2) } \\
\text { difTRADE_A }\end{array}$ & $\begin{array}{c}\text { (3) } \\
\text { difDEBT_A }\end{array}$ & $\begin{array}{c}\text { (4) } \\
\text { difROA1 }\end{array}$ & $\begin{array}{c}\text { (5) } \\
\text { difRE_TA }\end{array}$ & $\begin{array}{c}(6) \\
\text { difZscore }\end{array}$ \\
\hline \multirow[t]{2}{*}{ AFTER } & -0.007 & $0.045^{\star}$ & $-0.066^{\star \star \star}$ & $0.042^{*}$ & -0.047 & -0.092 \\
\hline & {$[0.17]$} & {$[1.66]$} & [2.78] & [1.78] & {$[0.86]$} & {$[0.37]$} \\
\hline \multirow[t]{2}{*}{ Pretrend } & $0.074^{\star \star \star}$ & $0.041^{\star \star \star}$ & 0.012 & $-0.068^{\star \star \star}$ & $-0.092^{\star \star \star}$ & $-0.536^{\star \star \star}$ \\
\hline & [3.81] & [3.01] & {$[1.05]$} & {$[6.26]$} & [3.97] & {$[4.47]$} \\
\hline \multirow[t]{2}{*}{ Postrend } & 0.016 & $0.020^{\star \star \star}$ & $-0.025^{\star \star \star}$ & $0.029^{\star \star \star}$ & $-0.096^{\star \star \star}$ & -0.04 \\
\hline & [1.33] & {$[2.67]$} & {$[4.17]$} & {$[4.59]$} & {$[4.83]$} & {$[0.53]$} \\
\hline \multirow[t]{2}{*}{ Pretrend*AFTER } & -0.018 & -0.008 & 0.003 & $0.028^{\star \star}$ & 0.014 & 0.155 \\
\hline & {$[0.87]$} & {$[0.55]$} & {$[0.24]$} & [2.40] & {$[0.59]$} & [1.20] \\
\hline \multirow[t]{2}{*}{ Postrend*AFTER } & 0 & -0.007 & 0.004 & -0.005 & 0.022 & $0.230^{\star \star}$ \\
\hline & {$[0.01]$} & {$[0.62]$} & {$[0.42]$} & {$[0.56]$} & {$[0.82]$} & {$[2.27]$} \\
\hline \multirow[t]{2}{*}{ Constant } & 0.320 *** & $0.037^{*}$ & $0.244^{\star \star \star}$ & $-0.257^{\star \star \star}$ & $-0.302^{\star \star \star}$ & $-2.522^{\star \star \star}$ \\
\hline & {$[9.36]$} & [1.68] & [13.05] & {$[12.62]$} & {$[6.43]$} & [12.54] \\
\hline Observations & 1975 & 1998 & 1945 & 1955 & 1962 & 1844 \\
\hline R-squared & 0.08 & 0.07 & 0.03 & 0.08 & 0.17 & 0.05 \\
\hline
\end{tabular}




\section{Table 6: Robustness to Crisis and Trend}

Variables are defined in Tables 3 and 4. Trend is a linear trend, defined as 1 for year 1996, 2 for year 1997, etc. Crisis dummies are defined for two different crisis windows - year 1999 and years 1998-2000, as labeled in column headings. In Panel A dependent variable is DURATION estimated using Cox proportional hazard model. Model 1 reproduces Model 1 from Table 3. Reported are hazard ratios and absolute values of z-statistics in brackets. In Panel B dependent variable is Z-score. Model 1 reproduces Model 7 from table 4. $* * *, * *$ and $*$ represent significance at the 1,5 , and 10 percent level.

\section{Panel A: Duration of Reorganization}

\begin{tabular}{|c|c|c|c|c|c|c|}
\hline & $\begin{array}{c}\text { (1) } \\
\text { Baseline }\end{array}$ & $\begin{array}{c}\text { (2) } \\
\text { Trend }\end{array}$ & $\begin{array}{c}\text { (3) } \\
\text { Crisis } 1999\end{array}$ & $\begin{array}{c}(4) \\
\text { Crisis } 1998- \\
2000 \\
\end{array}$ & $\begin{array}{c}\text { (5) } \\
\text { Crisis } 1999\end{array}$ & $\begin{array}{c}(6) \\
\text { Crisis 1998- } \\
2000 \\
\end{array}$ \\
\hline AFTER & $\begin{array}{l}0.827 \\
{[0.77]}\end{array}$ & $\begin{array}{l}0.831 \\
{[0.46]}\end{array}$ & $\begin{array}{l}0.835 \\
{[0.69]}\end{array}$ & $\begin{array}{l}0.871 \\
{[0.56]}\end{array}$ & $\begin{array}{l}0.837 \\
{[0.30]}\end{array}$ & $\begin{array}{l}1.131 \\
{[0.29]}\end{array}$ \\
\hline $\mathbf{R}$ & $\begin{array}{l}3.083^{\star \star \star} \\
{[8.30]}\end{array}$ & $\begin{array}{l}2.055^{\star \star} \\
{[2.02]}\end{array}$ & $\begin{array}{l}2.704^{\star \star \star} \\
{[5.97]}\end{array}$ & $\begin{array}{l}3.877^{\star \star \star} \\
{[6.11]}\end{array}$ & $\begin{array}{l}2.154^{*} \\
{[1.89]}\end{array}$ & $\begin{array}{l}2.186^{\star \star} \\
{[2.05]}\end{array}$ \\
\hline AFTER*R & $\begin{array}{l}14.535^{\star \star \star} \\
{[10.58]}\end{array}$ & $\begin{array}{l}5.588^{\star \star \star} \\
{[4.15]}\end{array}$ & $\begin{array}{l}16.632^{\star \star \star} \\
{[10.38]}\end{array}$ & $\begin{array}{l}13.811^{\star \star \star} \\
{[10.23]}\end{array}$ & $\begin{array}{l}3.658^{*} \\
{[2.13]}\end{array}$ & $\begin{array}{l}4.063^{\star \star \star} \\
{[3.24]}\end{array}$ \\
\hline Trend & & $\begin{array}{l}1.043 \\
{[0.37]}\end{array}$ & & & $\begin{array}{l}1.033 \\
{[0.21]}\end{array}$ & $\begin{array}{l}0.95 \\
{[0.40]}\end{array}$ \\
\hline Trend*R & & $\begin{array}{l}1.272^{\star \star \star} \\
{[2.12]}\end{array}$ & & & $\begin{array}{l}1.357^{*} \\
{[1.93]}\end{array}$ & $\begin{array}{l}1.393^{\star \star} \\
{[2.53]}\end{array}$ \\
\hline Crisis & & & $\begin{array}{l}0.974 \\
{[0.10]}\end{array}$ & $\begin{array}{l}1.339 \\
{[1.24]}\end{array}$ & $\begin{array}{l}0.996 \\
{[0.001]}\end{array}$ & $\begin{array}{l}1.543^{*} \\
{[1.68]}\end{array}$ \\
\hline Crisis* $R$ & & & $\begin{array}{l}1.514 \\
{[1.45]}\end{array}$ & $\begin{array}{l}0.711 \\
{[1.41]}\end{array}$ & $\begin{array}{l}0.57 \\
{[1.44]}\end{array}$ & $\begin{array}{l}0.619^{*} \\
{[1.81]}\end{array}$ \\
\hline N. Obs & 1896 & 1896 & 1896 & 1896 & 1896 & 1896 \\
\hline
\end{tabular}


Panel B. Z-score

\begin{tabular}{|c|c|c|c|c|c|c|}
\hline & (1) & $(2)$ & (3) & $(4)$ & (5) & (6) \\
\hline & Baseline & Trend & Crisis 1999 & Crisis 1998-2000 & Crisis 1999 & Crisis 1998-2000 \\
\hline \multirow[t]{2}{*}{ After } & $0.323^{*}$ & $0.688^{\star \star}$ & 0.152 & $0.309 *$ & 0.323 & $0.675^{\star \star}$ \\
\hline & {$[1.90]$} & [2.38] & {$[0.83]$} & {$[1.87]$} & {$[0.75]$} & {$[2.26]$} \\
\hline \multirow[t]{2}{*}{ B } & $-2.567^{\star \star \star}$ & $-2.843^{\star \star \star}$ & $-2.684^{\star \star \star}$ & $-2.664^{\star \star}$ & $-2.895^{\star \star \star}$ & $-2.835^{\star \star \star}$ \\
\hline & {$[9.69]$} & {$[4.72]$} & [9.19] & {$[7.45]$} & {$[4.54]$} & {$[4.77]$} \\
\hline \multirow[t]{2}{*}{ After*B } & $-2.125^{\star \star \star}$ & $-2.412^{\star \star}$ & $-2.010^{\star \star \star}$ & $-2.096^{\star \star *}$ & $-2.422^{\star \star \star}$ & $-2.187^{\star \star}$ \\
\hline & {$[3.62]$} & {$[2.43]$} & [3.35] & [3.62] & [2.03] & [2.18] \\
\hline \multirow[t]{2}{*}{$B^{*} R$} & -0.246 & -0.113 & -0.235 & -0.207 & 0 & -0.159 \\
\hline & {$[0.94]$} & {$[0.19]$} & {$[0.81]$} & {$[0.59]$} & {$[0.00]$} & {$[0.27]$} \\
\hline \multirow[t]{2}{*}{ After*B* $R$} & $1.772^{\star \star \star}$ & $1.885^{\star}$ & $1.761^{\star \star \star}$ & $1.767^{\star \star \star}$ & $2.205^{\star}$ & $1.681^{\star}$ \\
\hline & [3.06] & [1.92] & [2.97] & {$[3.09$} & [1.88] & {$[1.70]$} \\
\hline \multirow[t]{2}{*}{ Size } & $0.180 * \star \star$ & $0.177^{\star \star \star}$ & $0.177^{\star \star \star}$ & $0.180^{* * *}$ & $0.177^{\star \star \star}$ & $0.176^{\star \star \star}$ \\
\hline & [3.50] & {$[3.46]$} & [3.44] & [3.50] & [3.44] & [3.45] \\
\hline \multirow[t]{2}{*}{ Age } & 0.018 & 0.018 & 0.025 & 0.018 & 0.022 & 0.018 \\
\hline & [0.25] & {$[0.25]$} & [0.33] & [0.25] & [0.29] & {$[0.25]$} \\
\hline \multirow[t]{2}{*}{ Trend } & & -0.116 & & & -0.044 & -0.114 \\
\hline & & [1.54] & & & {$[0.43]$} & [1.49] \\
\hline \multirow[t]{2}{*}{ Trend*B } & & 0.093 & & & 0.103 & 0.04 \\
\hline & & [0.43] & & & {$[0.40]$} & [0.17] \\
\hline \multirow[t]{2}{*}{ Trend*B*R } & & -0.041 & & & -0.112 & 0.012 \\
\hline & & [0.19] & & & {$[0.44]$} & {$[0.05]$} \\
\hline \multirow[t]{2}{*}{ Crisis } & & & $-0.440 * \star$ & -0.055 & -0.359 & -0.036 \\
\hline & & & [2.03] & {$[0.34]$} & [1.20] & [0.22] \\
\hline \multirow[t]{2}{*}{ Crisis*B } & & & 0.233 & 0.182 & 0.032 & 0.25 \\
\hline & & & [0.35] & [0.39] & [0.04] & [0.50] \\
\hline \multirow[t]{2}{*}{ Crisis* $B^{*} R$} & & & 0.058 & -0.096 & 0.271 & -0.188 \\
\hline & & & [0.09] & {$[0.21]$} & {$[0.34]$} & [0.38] \\
\hline \multirow[t]{2}{*}{ Constant } & -0.489 & -0.09 & -0.238 & -0.454 & -0.132 & -0.07 \\
\hline & {$[0.46]$} & [0.09] & {$[0.22]$} & {$[0.42]$} & {$[0.12]$} & [0.07] \\
\hline N. Obs & 1974 & 1974 & 1974 & 1974 & 1974 & 1974 \\
\hline R-squared & 0.3 & 0.3 & 0.32 & 0.3 & 0.3 & 0.3 \\
\hline
\end{tabular}




\section{Figure 1. Liquidation vs. Reorganization Decision Before and After the Law}

This figure plots the payoffs to liquidation (horizontal line at $L$ ) and reorganization (increasing lines) as a function of observed cashflow at date $1 x_{1}$ when the firm is in distress, $x_{1}<p$. The left panel shows a high reorganization cost regime, while the right panel shows low reorganization costs. The payoffs to reorganization are given by $E\left[n\left(x_{2}\right) \mid x_{1}\right]$, ignoring subscripts, and therefore depend on reorganization costs. The top increasing line from 0 to $x_{p}$ and horizontal at $p$ for $x_{1}>x_{p}$ represents the payoff to reorganization when expected reorganization costs are zero, while the bottom increasing line from 0 to $p$ represents the payoff to reorganization when expected reorganization costs are maximal, $\bar{c}_{B}\left(x_{2}\right)$ in the left panel and $\bar{c}_{A}\left(x_{2}\right)$ in the right one. The top of each panel also reports the regions where the bank will decide to reorganize $(\mathrm{R})$ or liquidate $(\mathrm{L})$ the distressed firm. Before the law (left panel) there is no region where liquidation or reorganization alone dominates the other decision. Banks will restructure or liquidate depending on the expected reorganization costs. After the law (right panel), if observed cash-flow at date $1 x_{1}$ is higher than $x^{*}$ the bank will always decide to reorganize.

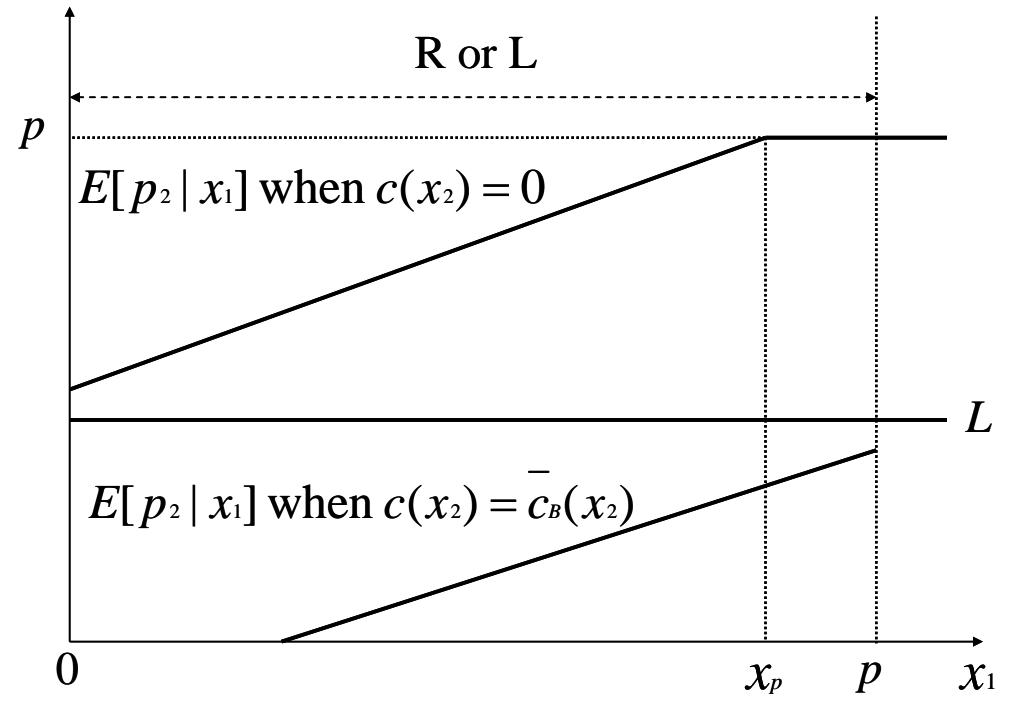

Before the Law

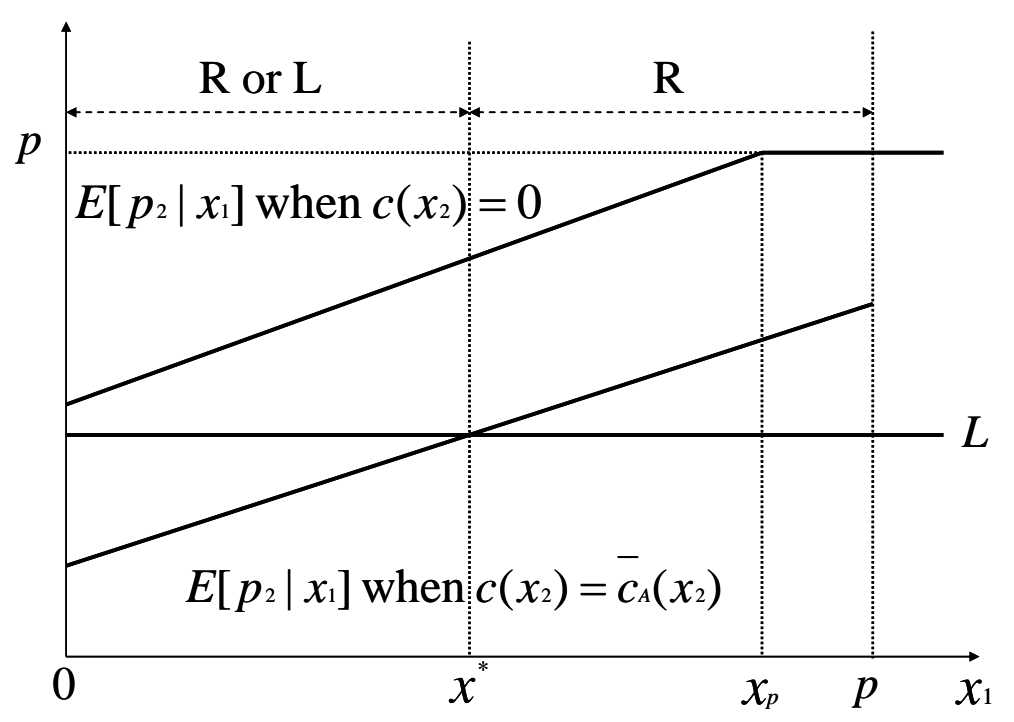

After the Law 


\section{Figure 2. Distribution of Z-scores Before and After the Law}
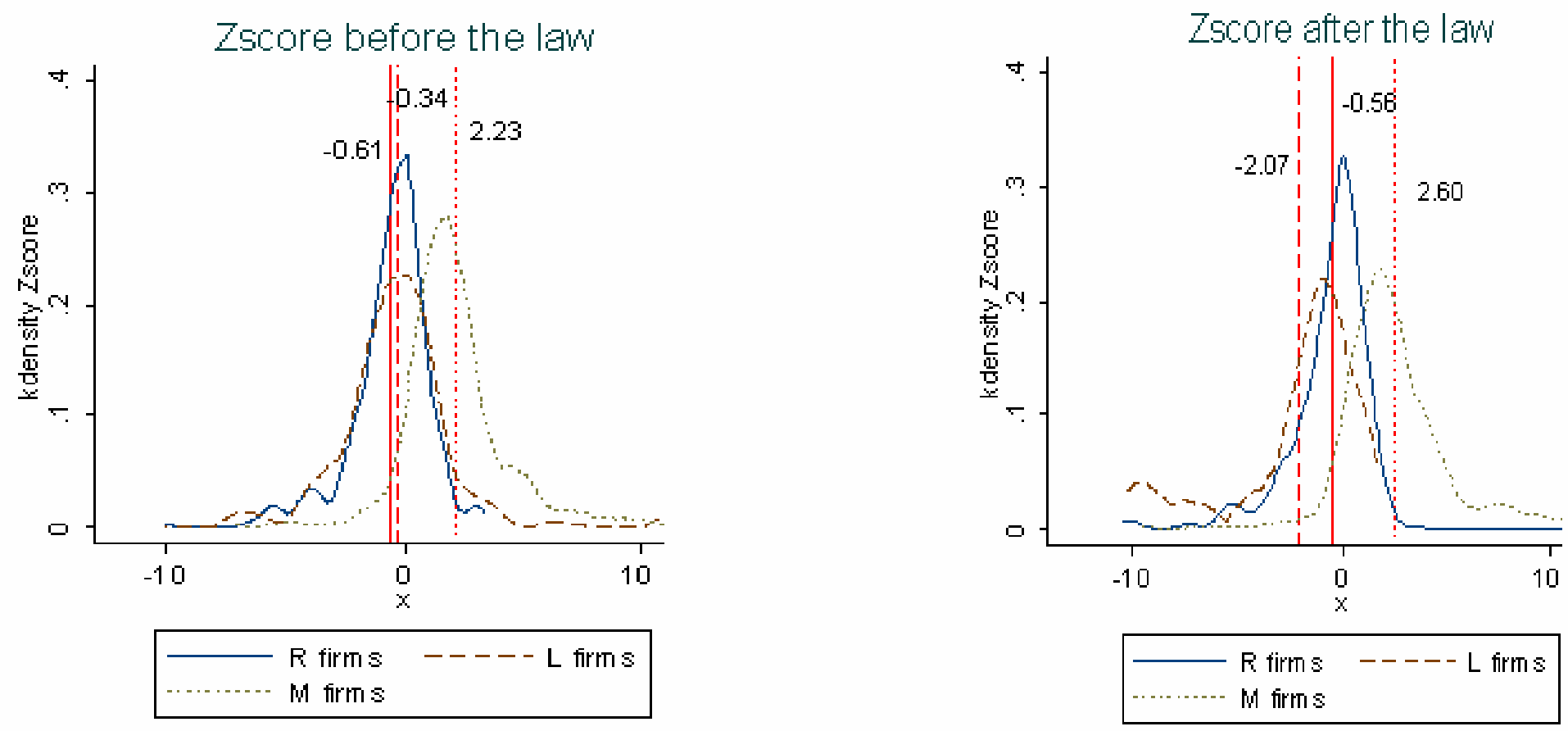
Figure 3. Time-series trends before and after the filing

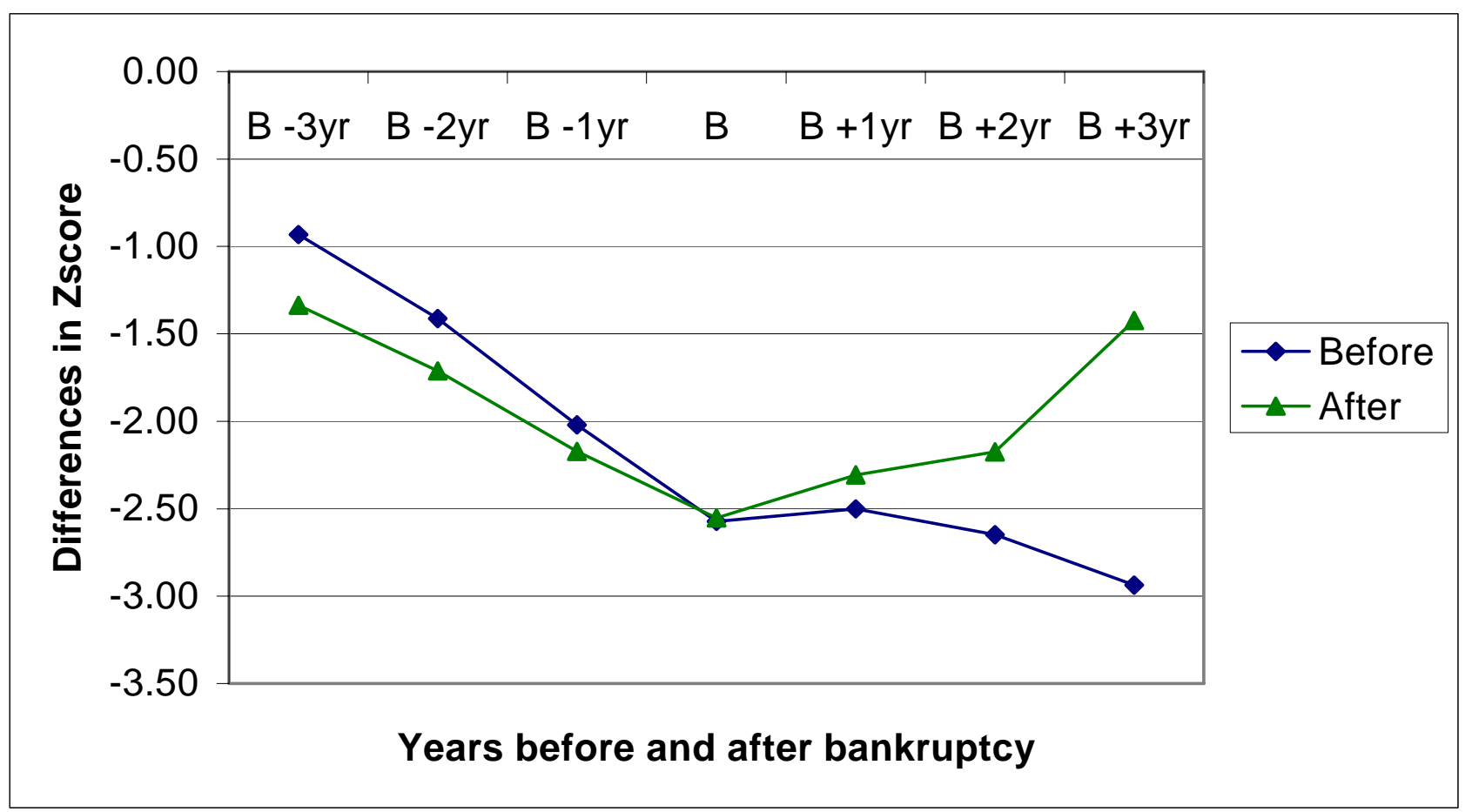

